\title{
Barriers and Bridges in Abating Coastal Eutrophication
}

\author{
Donald F. Boesch* \\ University of Maryland Center for Environmental Science, Cambridge, MD, United States
}

Over the past 30 years concerted campaigns have been undertaken to reverse nutrient-driven eutrophication in coastal waters in Europe, North America, Asia, and Australia. Typically, eutrophication abatement has proven a more recalcitrant challenge than anticipated, with ecosystem improvements only recently beginning to emerge or falling short of goals. Reduction in nutrient loads has come mainly from advanced treatment of wastewaters and has lagged targets set for diffuse agricultural sources. Synthesis of the major campaigns - varying in terms of physical settings, ecosystem characteristics, nutrient sources, socio-economic drivers, and governance-identified barriers inhibiting eutrophication abatement and potential bridges to overcome them. Actionable science can be advanced by: application of the well-established and emerging knowledge and experience around the globe, client-responsive strategic research, and timely and conclusive adjudication of scientific controversies. More accountable governance requires: enduring engagement of high-level officials of the responsible governments; effective communication of the causes, risks and benefits to the public and stakeholders; quantitative and accountable allocation of responsibility

OPEN ACCESS

Edited by:

Dorte Krause-Jensen, Aarhus University, Denmark

Reviewed by: Robinson W. (Wally) Fulweiler, Boston University, United States Jonathan Lefcheck, Smithsonian Institution, United States

*Correspondence: Donald F. Boesch boesch@umces.edu

Specialty section:

This article was submitted to Marine Ecosystem Ecology, a section of the journal Frontiers in Marine Science

Received: 28 September 2018 Accepted: 28 February 2019 Published: 18 March 2019

Citation:

Boesch DF (2019) Barriers and Bridges in Abating Coastal Eutrophication. Front. Mar. Sci. 6:123. doi: 10.3389/fmars.2019.00123 for nutrient load reductions; and binding requirements, as opposed to simply voluntary actions. Effective reduction in nutrient loads requires: reduction strategies for both nitrogen and phosphorus; inclusion of actions that reduce atmospheric emissions of nitrogen in addition to direct inputs to waterways; efficacious regulations; public subsidies based on performance; limitations on biofuel production that increases nutrient loads; and enhancing the sinks and losses for legacy nutrients retained in soils and groundwater. Outcomes must be measured and strategies appropriately adjusted through: sustained monitoring of essential indicators and processes, the use of multiple models, truly adaptive management, and cautious interventions within the coastal ecosystem. The changing climate must be taken into account by reassessing achievable future conditions and seeking alternatives for mitigating and adapting to climate change that also reduce nutrient loads.

\footnotetext{
Keywords: eutrophication - applied issues, coastal ecosystems, nutrients (nitrogen and phosphorus), hypoxia/reoxygenation, agriculture, Baltic, Chesapeake Bay United States, Gulf of Mexico
}

\section{INTRODUCTION}

Cultural eutrophication has resulted in consequential changes in coastal ecosystems around the world. Early concerns focused on organic inputs from sewage and industrial wastes. As treatment of these discharges improved, it became clear that inputs of nutrient elements, particularly forms of nitrogen and phosphorus from treated waste and diffuse agricultural and atmospheric 
sources, had more expansive consequences detrimental to human uses and ecosystem health. These consequences include diminished water clarity, harmful and nuisance algal blooms, oxygen deficient or hypoxic zones, and degradation of habitats important for living resources.

Extensive scientific research has focused on the progression, causes and effects of eutrophication of coastal ecosystems around the world that became evident in the latter 20th century. A decade ago, Nixon (2009) noted that while many efforts were underway to reduce nutrient loads to degraded coastal ecosystems, there was sparse documentation of the responses to this "oligotrophication" or trend reversal. A burgeoning literature has now emerged on the abatement of nutrient loading and the attendant responses of coastal ecosystems and their catchments (Carstensen et al., 2011).

Abatement of eutrophication does not necessarily lead to restoration of the coastal ecosystems to some previous state (Duarte et al., 2009), but could nonetheless lead to rehabilitation of important ecosystem functions (Choi, 2007) or reconciliation with human uses (Rosensweig, 2003). Effectiveness of abatement is generally evaluated with respect to predetermined objectives such as reduction in nutrient loads, improved water clarity, reduced hypoxia or incidence of harmful algal blooms, or recovery of submersed vegetation or other biotic components of the ecosystem. Measured against such metrics, responses have variously been effective, ineffective, recalcitrant and sometimes surprising.

The goal of this review is less an evaluation of ecosystem responses, but rather the extent to which organized campaigns to abate eutrophication around the world have achieved their management objectives. I explore how, based on this experience, both scientists and society can better navigate obstacles and find effective solutions.

This review is derived from my presentation at the Fourth International Symposium on Research and Management of Eutrophication in Coastal Ecosystems in Nyborg, Denmark, in June 2018. As a framework for assessment of the global experience I chose the metaphors of barriers and bridges used in a book entitled Barriers and Bridges to the Renewal of Ecosystems and Institutions (Gunderson et al., 1995). The book's editors, early thought leaders in ecosystem resilience theory and adaptive management, assembled six case studies to assess how can barriers be broken and bridges built for effective regional ecosystem management. Two of those case studies focused on the Chesapeake Bay (Costanza and Greer, 1995) and the Baltic Sea, large ecosystems where abatement of coastal eutrophication has been a central and concerted focus for both research and management. In the Baltic chapter, Jansson and Velner (1995) reflected on the recent contentious decision to build the Öresund Bridge between Sweden and Denmark. Building bridges seemed to me to be an apt metaphor for a symposium held at the foot of the Belt Sea Bridge in a nation long at the forefront of abating eutrophication and now interconnected by monumental bridges.

Here I review the major campaigns to abate coastal eutrophication in Europe, North American, Asia, and Australia (Figure 1). The socio-environmental systems explored vary considerably in terms of physical settings, ecosystem characteristics, nutrient sources, socio-economic drivers, and governance, offering a rich case studies for instructive synthesis. I then offer my perspectives on barriers and bridges to future approaches for achieving eutrophication abatement objectives (Table 1). The relevant literature has already become vast; thus, I cite more recent references rather than provide comprehensive documentation.

\section{EUROPE}

\section{European Union Directives}

The abatement of eutrophication in the coastal seas of Europe is a central focus of several regional sea conventions among littoral and riparian nations. The actions taken by the European Unionmember parties to these conventions are generally in conjunction with the implementation of several EU directives. A directive, in contrast to a regulation, is an act that requires member states to achieve a particular result without dictating the means of achieving that result. The Urban Waste Water Treatment Directive, adopted in 1991, has the objective to protect the environment from adverse effects of urban and certain industrial wastewater discharges, encompassing collection, treatment and discharge. The Nitrates Directive (NiD), adopted in 1991, aims to protect water quality by preventing agricultural sources from polluting ground and surface waters through promoting good farming practices. The Water Framework Directive (WFD), adopted in 2000, committed EU member states to achieve good environmental status by 2015 for all water bodies, including marine waters up to one nautical mile from shore. The Marine Strategy Framework Directive (MSFD), adopted in 2008, aims at achieving and maintaining good environmental status in European seas by 2020. The European Commission has produced a set of detailed criteria and methodological standards to help member states implement the MSFD, including abating eutrophication. The MSFD distinguishes four European marine regions located within the geographical boundaries of existing regional sea conventions: the Baltic Sea, the North-East Atlantic Ocean, the Mediterranean Sea and the Black Sea.

\section{Baltic Sea}

Abatement of eutrophication in the Baltic Sea has received more concerted effort and sustained research than any other coastal region in the world. The Baltic Sea: (a) has a wet and largely boreal climate; (b) is an expansive $\left(415,000 \mathrm{~km}^{2}\right)$ and relatively shallow, shelf-sea (mean depth $58 \mathrm{~m}$ ), but with deeper $(>110 \mathrm{~m})$ basins and a shallow restricted connection with the North Sea; and (c) has a vast catchment (1.64 million $\mathrm{km}^{2}$ ) inhabited by over 85 million people (Reusch et al., 2018). These characteristics combine to create a brackish, tideless sea with year-round thermal stratification that is highly susceptible to eutrophication. Stratification isolates the deeper basins, making them vulnerable to year-round hypoxia that developed during the 20th century and is unprecedented during at least the prior 1,500 years (Jokinen et al., 2018). The hypoxic basins are influenced not only by nutrient-driven productivity, but also periodic intrusions of more saline waters from the North Sea. 


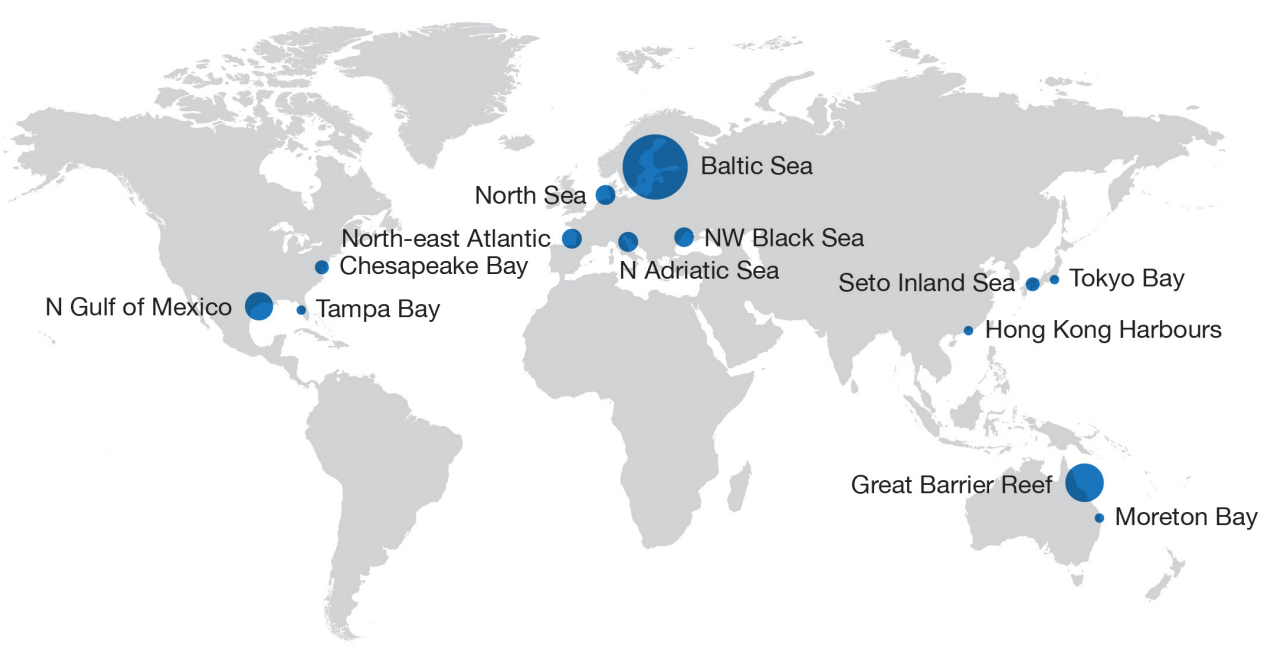

FIGURE 1 | Location of major campaigns to abate coastal eutrophication discussed in this paper. Size of the circles is roughly proportional to the area affected by eutrophication.

TABLE 1 | Barriers and bridges in abating coastal eutrophication.

\begin{tabular}{|c|c|c|}
\hline Themes & Barriers & Bridges \\
\hline \multirow[t]{3}{*}{ Advancing actionable science } & Limited knowledge of causes and consequences & Apply knowledge and approaches to other regions \\
\hline & Fragmentary scientific understanding & Client-responsive strategic research \\
\hline & Paralyzing scientific controversies & Responsive and conclusive adjudication \\
\hline \multirow[t]{4}{*}{ Providing accountable governance } & Mid-level managers lack authority and responsibility & Enduring engagement of high-level, responsible parties \\
\hline & Limited public and stakeholder concern & Effective communication of causes, risks and benefits \\
\hline & Overgeneralized commitments & Quantitative allocation and accountability \\
\hline & Voluntary, non-binding commitments & Statutory requirements \\
\hline \multirow[t]{5}{*}{ Reducing nutrient loads } & Narrow debates over limiting nutrients & Holistic nitrogen plus phosphorus strategies \\
\hline & $\begin{array}{l}\text { Atmospheric nutrient sources beyond control of water } \\
\text { managers }\end{array}$ & $\begin{array}{l}\text { Air quality regulations can result in substantial } \\
\text { reductions in nitrogen }\end{array}$ \\
\hline & Voluntary implementation of practices & Performance compliance or regulation \\
\hline & Expanding production of biofuels & Accelerate transition to cellulosic biofuels \\
\hline & Legacies and lags & $\begin{array}{l}\text { Include in models, focus on sources with more } \\
\text { immediate pathways, and enhance sinks and losses in } \\
\text { catchments }\end{array}$ \\
\hline \multirow[t]{5}{*}{ Assessing outcomes and adapting strategies } & Inadequate or underused monitoring & $\begin{array}{l}\text { Sustained monitoring of essential indicators and } \\
\text { processes, periodic scorecards }\end{array}$ \\
\hline & Inadequate or overprescribed modeling & Multiple models appropriate for guiding management \\
\hline & Over-reliance on model assumptions not reconciled & Truly adaptive management based on integrated \\
\hline & with observations & modeling and monitoring \\
\hline & Rehabilitation stalled or delayed despite reduced loads & $\begin{array}{l}\text { Consider intervention options within coastal } \\
\text { ecosystems or modification of goals }\end{array}$ \\
\hline \multirow[t]{2}{*}{ Addressing climate change } & $\begin{array}{l}\text { Goals unachievable or only after impractical additional } \\
\text { load reductions }\end{array}$ & $\begin{array}{l}\text { Reassess achievable future conditions to inform } \\
\text { climate-smart strategies }\end{array}$ \\
\hline & Decoupled water-quality and climate change strategies & $\begin{array}{l}\text { Seek mitigation and adaptation alternatives that limit } \\
\text { climate change and reduce nutrients loads }\end{array}$ \\
\hline
\end{tabular}

In addition, eutrophication has diminished water clarity, caused toxic or noxious algal blooms, resulted in localized hypoxia, and reduced or altered macrovegetation in nearshore environments, fjords, lagoons and archipelagos around the Baltic.

Faced with mounting evidence of environmental degradation, in 1974 Baltic Sea nations joined in the Convention on the Protection of the Marine Environment of the Baltic
Sea, better known as the Helsinki Convention. The Helsinki Commission (HELCOM) implements the Convention's plans and directives through its ten contracting parties: Denmark, Sweden, Finland, Germany, Poland, Lithuania, Latvia, Estonia, the Russian Federation, and the European Union. All sovereign parties except Russia are, since 2004, members of the EU. The Heads of Delegation of the contracting parties, typically 
nations' environmental ministers, are responsible for HELCOM decisions and national implementation. Commitments made are considered binding, although the consequences of noncompliance have not been tested.

A HELCOM Ministerial Declaration stipulated in 1988 that by 1995 emissions of nitrogen and phosphorus to the Baltic Sea should be reduced by $50 \%$ of the 1985 emissions level. These ambitious targets were not met and in 2007 HELCOM launched the Baltic Sea Action Plan (BSAP) that set new targets requiring a decrease in nitrogen and phosphorus loads by 16 and $70 \%$, respectively, from 1997-2003 loads by 2015 (Elofsson and von Brömssen, 2017). Determination of Maximum Allowable Inputs (MAI) of nutrients relied on models covering the entire sea and catchment that are used to allocate the reduction burden among sub-basins and countries. Allocations are refined on an ongoing basis based on new data and model refinements. Wulff et al. (2014) estimated that if control measures are optimized the annual costs to meet the BSAP basin targets would be $€ 4.7$ billion.

Substantial reductions in nutrient loads from their peaks in the 1980s have been achieved for both nitrogen and phosphorus, about 24 and 50\%, respectively (Reusch et al., 2018). Most of these reductions have come from improvements in wastewater treatment plants, driven largely by the EU's Urban Waste Water Treatment Directive. Further load reductions of about 16 and $38 \%$ from present estimated loads, for nitrogen and phosphorus, respectively, are required to meet the BSAP targets. Inputs from diffuse sources, largely agriculture, have been the most difficult to reduce. The difficulty in achieving reductions is compounded by the legacy storage of nutrients in soils and waterways, for phosphorus, and groundwater, for nitrogen. McCrackin et al. (2018) estimated the residence time for phosphorus in Baltic catchments of about 30 years, but concluded that the system has shifted from accumulation to depletion of legacy storage. While it remains difficult to achieve near-term goals for load reductions to the sea, addressing pathways of rapid transport such as overland flow, and mobile stores, such as cropland with large soil-phosphorus reserves, would accelerate load reductions.

Phosphorus also has a long residence time within the Baltic Sea and its coastal waters that delays alleviation of eutrophication symptoms even after anthropogenic loadings are reduced. While efforts were being made to reduce loadings from land, the phosphorus pools in Baltic Sea basins were increasing (Savchuk, 2018). As flow restrictions at the sea's entrance greatly limit phosphorus export, the only loss is to sediment deposition. However, a "vicious circle" of nutrient limitation coupled with hypoxia compounds and prolongs the effect of the accumulated phosphorous in the open Baltic (Vahtera et al., 2007). Hypoxic bottom waters release phosphate that supports the growth of nitrogen-fixing cyanobacteria once surface-water nitrogen supplies are depleted. Enhanced primary production intensifies bottom-water hypoxia that, in turn, fuels more intensive cyanobacteria blooms, particularly in summers such as in 2018 when surface waters are warm and winds weak. The manifestations of eutrophication in the open Baltic, hypoxia and cyanobacterial blooms, may not be abated for many decades. Still, improvements in a multi-component indicator of eutrophication have been in evidence in several Baltic Sea basins beginning in the 1990s. Modeling suggests that if the BSAP load reduction targets are met "good ecological status" would be achieved in the 2030s in the Arkona Basin and in the 2060s in the Kattegat, Bornholm Basin and Gulf of Finland (Murray et al., 2019).

Some businesses, politicians and scientists have advocated quicker alternatives, such as mechanical oxygenation or chemical stabilization of the phosphorus (Conley, 2012). Debates among Baltic scientists over geoengineering, as well as over the efficacy of reductions of nitrogen loads (Schindler et al., 2008; Conley et al., 2009), have sometimes been as vicious as these biogeochemical cycles.

Eutrophication in nearshore waters is directly problematic for citizens and resource users as it results in reduced water clarity, consequent loss of attached plants such as Zostera and Fucus, fish kills, and nuisance accumulation of macroalgae. Hypoxia has also been increasing at many coastal zone sites (Conley et al., 2011). Eutrophication abatement in these environments has usually been addressed by national level actions, but also within the framework of the EU's WFD and MSFD and the HELCOM's BSAP. The need for reduction in nitrogen loads to coastal waters, despite the aforementioned controversies, has now been clearly demonstrated through improvements in water quality and biological conditions following reductions in nitrogen loading, without the confounding effects of nitrogen fixation, in Danish coastal waters (Riemann et al., 2016; Staehr et al., 2017) and Swedish fjords (Savage et al., 2010; Walve et al., 2018).

Experiences in Danish estuaries and coastal waters (including along the North Sea coast) are particularly instructive. Growing environmental deterioration during the 1970s was brought to a head by a fish and shellfish-killing episode of hypoxia in the Kattegat in 1981. This motivated the enactment in 1987 of the Danish National Action Plan on the Aquatic Environment, aimed at reducing nitrogen and phosphorus discharges by 50 and $80 \%$, respectively. A succession of additional agricultural measures was imposed, including limiting nitrogen application to $10 \%$ (later $15 \%$ below) below the economic optimum rate and obligatory planting of catch crops (Hansen et al., 2017). Sustained and coupled monitoring and assessment programs were established in 1988 to follow the outcomes, including: implementation of agricultural practices; changes in nutrient concentrations in nutrients in groundwaters, surface waters and marine waters; and biological responses. By around 2003, declines in nitrogen leaving the land were evident as follows: discharges from point sources by $74 \%$, the nitrogen surplus in agriculture (the amount of nitrogen applied less the nitrogen removed in crops) by $31 \%$, leaching from the root zone in agricultural land by $33 \%$, and concentrations in streams by $29-32 \%$ (Kronvang et al., 2008). After another decade of observations, an assessment concluded that nutrient inputs from land to Danish coastal ecosystems were reduced by about $50 \%$ for nitrogen and $76 \%$ for phosphorus since 1990 (Riemann et al., 2016). This was accompanied by concomitant shifts in nutrient concentrations in receiving waters, reduced phytoplankton biomass, increased macroalgae coverage and expansion of eelgrass meadows. However, bottom water oxygen conditions in deeper water did 
not improve, ostensibly because of more frequent stratification and warmer temperatures.

Ecosystem responses to the abatement of eutrophication can be recalcitrant even when nutrient pollution reduction goals are met. There are myriad reasons for falling short in the "return to Neverland" as Duarte et al. (2009) frame this dilemma. These include both lags in nutrient delivery from the catchment and continued release of accumulated internal loads, as well as "state changes" due to changing climatic conditions, food chain shifts, invasive species and the dislocation of ecosystem engineers. As an example of the last, along the Swedish Kattegat coast, 60\% of the eelgrass meadows were lost since the 1980s, but failed to recover despite a significant reduction of nutrient loads and in nitrogen concentrations (Moksnes et al., 2018). Wind-driven resuspension of sediments destabilized by the loss of eelgrass beds limited light penetration and, thus, eelgrass recolonization of deeper bottoms. Drifting algal mats-attributed to overfishing of predators-also cover eelgrass meadows. These feedbacks spread the loss of eelgrass into neighboring areas. Recovery from hypoxia in basins in the Archipelago Sea of Finland is made difficult both by postglacial uplift, that further isolates basins and results in remobilization of organic matter as the wave base shifts and the reduced ice cover prolongs the period experiencing surface waves, as well as by warming surface waters (Jokinen et al., 2018). Regionally specific processes affect recovery, which can be idiosyncratic.

The effects of climate change on rehabilitation of eutrophication have received particular attention for the Baltic Sea, where the climate has already rapidly changed. Water temperatures will continue to rise and river discharges are projected to increase at these latitudes. Changes in wind velocity and direction are also thought to have effects. The general consensus of models and assessments is that climate change will make it more difficult to achieve the goals of the EU directives and the BSAP to achieve and maintain good environmental status that is benchmarked on some earlier condition (Neumann et al., 2012). Nonetheless, models indicate that, while the warming climate might amplify the effects of eutrophication, nutrient load reductions following the BSAP will lead to improved environmental conditions even under future climate changes (Saraiva et al., 2018).

Reusch et al. (2018) make the case for the Baltic Sea as a "time machine," or harbinger of future interactions between climate change and other human impacts in coastal ocean environments more generally. As we move to consider experiences in abating eutrophication in other parts of the world there are several things to keep in mind from the Baltic experience: (a) Baltic nations have sustained a ministerial-level commitment though HELCOM for nearly 45 years and have allocated nutrient load reduction targets that are considered binding. (b) The scientific capacity, activity and engagement in this area surpass by far that of any other region in the world. In particular, strategic transdisciplinary research that is internationally collaborative has been further enhanced by the BONUS Programme: Science for a Better Future of the Baltic Sea (Snoeijs-Leijonmalm et al., 2017). This program has harmonized national research funding and heavily leveraged it with European Commission support. (c) To varying degrees there has been a commitment to environmental monitoring of outcomes and periodic assessments of eutrophication status (e.g., Andersen et al., 2015). (d) Substantial reductions in nutrient loads have been achieved, but reductions from diffuse sources, particularly agriculture, have lagged. Except for the more aggressive approaches pursued by Denmark, efforts under the Nitrates Directive and other EU directives have been insufficient to achieve agricultural source reduction targets. Furthermore, delayed responses as a result of soil, groundwater, and watershed storage and legacy internal loads further compound this recalcitrance.

\section{North Sea}

The North Sea is a relative shallow shelf-sea (mean depth of $90 \mathrm{~m}$ ) that, unlike the Baltic Sea, has dynamic exchange with the Atlantic Ocean (Emeis et al., 2015) and consequently residence times of less than 1 month for the coastal North Sea as opposed to 4.5 years for the Baltic Proper (Artioli et al., 2008). While several British estuaries are eutrophied, the designated problem areas for eutrophication in the sea itself lie mainly along its southeastern margins along the continental coast (Claussen et al., 2009). This shallow $(<50 \mathrm{~m})$ region is well mixed and receives the discharge of several rivers (Meuse, Scheldt, Rhine, Ijssel, Ems, Weser, and Elbe) that drain catchments totaling $428,500 \mathrm{~km}^{2}$, populated by 140 million inhabitants (Emeis et al., 2015).

The North Sea is also the subject of a regional seas convention, OSPAR, effectively the merger in 1992 of the previous Oslo Convention of 1972, covering the dumping of wastes at sea, and the Paris Convention of 1974, covering land-based sources of marine pollution and the offshore industry. The OSPAR Commission has jurisdiction for the broader European NorthEast Atlantic Ocean, thus has contracting parties additional to those counties that border the North Sea (Belgium, Netherlands, Germany, Denmark, Norway, and the United Kingdom). As recounted in detail by de Jong (2006), eutrophication began to command attention after the occurrence of hypoxic events in the German Bight of the North Sea in 1981 and 1982 that followed from the rapid growth of phosphorus and, particularly, nitrogen discharges from the continental rivers during the 1960s and 1970s. The environmental ministers of the OSPAR contracting parties agreed in 1987 to reduce the river loads of dissolved inorganic phosphorus and nitrogen to 50\% of the levels in 1985 by the year 1995 .

The phosphorus goal was actually exceeded due to improvements in wastewater treatment and the replacement of phosphates in detergents (Emeis et al., 2015). However, by 1995 dissolved inorganic nitrogen loads had only declined by about $20 \%$. Nutrient loads have continued to decline, reaching about $-81 \%$ for phosphorus and $-45 \%$ for nitrogen by 2010 . Any further reductions of nitrogen loads from the rivers will have to come from more effective controls on diffuse sources. Also notable are the reductions experienced in atmospheric deposition of nitrogen on the North Sea, which was of the same magnitude as the river loads in 1985. Deposition was almost halved by 2010 due to reductions in emissions of oxidized nitrogen from land-based sources. At the same time, nitrogen deposition from 
ship exhausts, responsible for about $17 \%$ of nitrogen deposition in the North Sea, is increasing.

Driven by the currents exiting the English Channel, the freshened and enriched surface plume off the river mouths flows along the coast to the north. It stimulates primary production not only in coastal waters, but also in the Wadden Sea, the expansive system of intertidal lagoons running from the Netherlands into Denmark. As loads of phosphorus were reduced more quickly and substantially than for nitrogen, the N/P-ratios in river discharges increased between 1980 and 1992, from 23 to 62 for the Rhine River and 75 to 124 for the Elbe River (Emeis et al., 2015). Primary production in waters near the river mouths was light or phosphorus-limited, thus reducing phosphorus loads allowed more excess nitrogen to be exported up the coast, expanding the reach of eutrophication until nitrogen loads were also reduced.

The environmental conditions in the Wadden Sea have reflected these changes (van Beusekom, 2005). Primary production increased threefold while nutrient loading from the rivers grew. Algal mats replaced seagrasses (Zostera spp.). A three-fold decline in the biomass of benthic infauna was observed in the portions of the Dutch Wadden Sea most affected by the Rhine discharge when phosphorus loading was reduced. In the more distal German Wadden Sea, a reduction of phytoplankton biomass was not seen until after nitrogen loads were also reduced. Despite the apparent abatement of eutrophication the ecosystem had not, however, returned to its previous state largely because of the changes in this intertidal ecosystem related to sea-level rise and invasions of non-indigenous species, including the marsh grass, Spartina anglica, and the introduced oyster Crassostrea gigas, which has supplanted mussel beds (Schumacher et al., 2014).

\section{North-East Atlantic Ocean}

Eutrophication of coastal waters along the Atlantic coast of Europe from the English Channel through the Iberian Peninsula is manifest in intense phytoplankton blooms, including some that produce nuisance foam events or toxins; local hypoxia; and changes in coastal communities. This eutrophication is caused primarily by the nitrogen and phosphorus enrichment of river discharges and to a lesser extent by atmospheric deposition of nitrogen (Desmit et al., 2018). The region also falls within the scope of the OSPAR Convention, which calls for reducing both nitrogen and phosphorus inputs from rivers by $50 \%$ compared with 1985 levels. As all the littoral nations are members of the European Union, they also are responsible for complying with the relevant EU directives (WFD, MSFD, UWWTD, and NiD).

Except for the Duoro River, all of the major rivers experienced substantial declines in total phosphorus discharge between 19911995 and 2001-2005, ranging from 30\% for the Loire and Tagus rivers to $55 \%$ for the Seine (Romero et al., 2013). Except for the Garonne River, loadings of total nitrogen generally increased during this period, by 27 and $22 \%$ for the two largest rivers, the Seine and the Loire. In the bay off the mouth of the Seine River, the decrease in phosphorus loads matched a general decrease in phytoplankton biomass in the summer, but the sustained high loads of nitrogen matched an increase in the abundance of dinoflagellates, including Phaeocystis responsible for foam events.
Declines in phosphorus discharges were largely due to the ban of phosphates in household detergents and phosphorus removal from wastewater discharges. In the well-monitored Seine River below Paris, treatment of point source discharges led to remarkable improvements in water quality, with sharp reductions in ammonium and phosphate and progressive increase in dissolved oxygen (Romero et al., 2016). Summer anoxia in the Seine estuary has nearly disappeared, aided, in part, by the recent introduction of denitrification of wastewaters. Measures to control nutrients from diffuse sources, particularly agriculture, have, however, been relatively ineffective. Nitrate concentrations increased by $150 \%$ between the 1980s and 2010, after which it showed some reversal of this trend. This is due to the ninefold increase in the use of nitrogen fertilizers after the 1950s, compounded by the promotion of artificial drainage of wetlands that reduced nitrogen retention within the watershed. Only a 2$3 \%$ decrease in nitrate was observed in the Seine after 2010 from what was reported in 1998, despite the fact that control measures to reduce the over-dosage of fertilizers have existed for over two decades. The reported nitrogen surplus for agricultural soils has decreased, so the lack of decline in the river might be due to insufficient reductions or to groundwater lag times that could extend several decades.

Ménesguen et al. (2018) modeled the amount and locations of the nutrient source reductions needed to achieve good ecological status within coastal waters. The ineffectiveness or inertia of present measures for reducing agricultural nutrient losses has also prompted use of these models to explore whether the eutrophication abatement goals of the EU's North-East Atlantic Ocean goals are achievable. Linking marine ecosystem models with outputs from a watershed model, Desmit et al. (2018) concluded that decreases in nitrogen fluxes from land sufficient to prevent eutrophication symptoms could not be achieved by implementing wastewater treatment and conventional good agricultural practices, alone. Achieving effective nutrient load reductions would likely entail substantial social, economic and agricultural changes that reshape connections between crop production and livestock farming, and between agricultural and local human food consumption. These changes include less waste production and a shift toward human diets where half of the animal products consumed are replaced by vegetal proteins, known as a demitarian diet.

\section{Mediterranean Sea}

While the Mediterranean Sea, like the Baltic, has limited exchange with the Atlantic Ocean, it is vastly larger and deeper. Moreover, evaporation from its surface exceeds freshwater inputs via precipitation and rivers. Consequently, its open waters have elevated salinities and are exceptionally oligotrophic. Eutrophication is in evidence in small coastal lagoons and bays affected by intense human activity (Karydis and Kitsiou, 2012). In more open waters, nutrients supplied by rivers are responsible for a large fraction of the pelagic primary production and for bottom hypoxic area only in the Adriatic and Aegean basins (Macias et al., 2017).

Largely based on concerns about pollution, the Mediterranean nations and the European Economic Community adopted 
the Mediterranean Action Plan, also known as the Barcelona Convention, in 1976. The Plan was amended in 1995 as the Convention for the Protection of the Marine Environment and the Coastal Region of the Mediterranean, which entered into force in 2004. Member states committed to adopt: measures against land-based pollution, protection of biological diversity, and pollution monitoring. In addition, all of the littoral nations along the northern coast except for Bosnia-Herzegovina, Montenegro, and Albania, are members of the European Union and bound to address the relevant EU directives discussed earlier. The MSFD recognizes a specific Mediterranean ecoregion and calls for achieving good environmental status in the marine environment by 2020, including specifically that human-induced eutrophication is minimized. In response to the MSFD, a Trophic Index (analogous to the HEAT index used for the Baltic) has been widely used to address eutrophication status in northern Mediterranean waters (Pavlidou et al., 2015). Some other non-EU nations on the Mediterranean have developed similar directives paralleling those of the EU.

The northern Adriatic Sea, the most extensive shallow area in the Mediterranean, has received the most attention regarding the effects and abatement of coastal eutrophication. Located between Italy and the Balkans and delimited by the $100 \mathrm{~m}$ isobath, its average depth is only $35 \mathrm{~m}$. Eutrophication was manifest in seasonal hypoxia in deep waters during the 1970s and 1980s that was severe enough to cause fish kills and regional elimination of benthic species. From the late 1980s there have been incidents of extensive mucilage production when algal blooms confront severe phosphorous limitation (Degobbis et al., 2005). Discharges from the Po River account for about $65 \%$ of the freshwater, nitrogen and phosphorus loads. The effects of associated eutrophication are strongly influenced by variations in circulation and climate. In the lagoons within the Po delta, macroalgal blooms also displaced seagrasses.

Nutrient loads from the Po declined beginning in the late 1980s, but particularly after 2000, and this was accompanied by reductions in soluble reactive phosphorus (SRP) concentrations, chlorophyll $a$, and plankton biomass in the northern Adriatic (Viaroli et al., 2018). This trend can be reversed during years of high river flow. Net anthropogenic phosphorus inputs to the Po catchment declined by $35 \%$ by around 2000 and the SRP loads from the river declined even more. The decline resulted not only from wastewater treatment but also retention of phosphorus in soils and sediments held within streams and rivers. Over the same time, net anthropogenic nitrogen inputs declined by about $18 \%$, but the dissolved inorganic nitrogen discharges from the river have remained unchanged. Consequently, there is currently a large excess in available $\mathrm{N}$ relative to $\mathrm{P}$ in the northern Adriatic, where the phytoplankton was already phosphorus-limited, causing shifts in micro- and macroalgae and mismatches between grazers and phytoplankton in food webs. The challenge, then, is to reduce loadings of nitrogen by more efficient agricultural practices and by restoring biogeochemical processes in irrigation and drainage ditches, streams and the river that promote denitrification. Abating eutrophication of the coastal waters of the northern Adriatic will require harmonizing policies over large spatial scales and restoring the Po river basin.

\section{Black Sea}

The Black Sea is even more confined than the Mediterranean, but is brackish because of large freshwater inputs. Permanently stratified, it has a large and deep anoxic basin. Concerns about anthropogenic eutrophication are limited to the sea's margins, in particular on the expansive northwestern continental shelf that receives the discharge of the largest rivers flowing into the Black Sea, the Dniester, Dnieper, and particularly the Danube. Because of low sedimentation rates and clear waters, the northwestern shelf harbored a rich benthic biota, characterized by an expansive field of the red macroalga Phyllophora and large populations of the filter feeding mussel, Mytilus galloprovincialis (Mee, 2006). Soviet scientists documented the development and expansion of seasonal hypoxia in bottom waters that grew from $3,500 \mathrm{~km}^{2}$ and around $30 \mathrm{~m}$ deep in 1973 to $30,000 \mathrm{~km}^{2}$ from 15 to $45 \mathrm{~m}$ deep by 1978 (Capet et al., 2013). The Phyllophora field and mussel beds were largely destroyed in the affected area, either due to the lack of oxygen or reduced light availability. Over-fishing and the proliferation of an invasive ctenophore that altered foodwebs combined to cause a collapse and loss in resilience of this productive ecosystem (Mee et al., 2005).

Not surprisingly, the development of hypoxia followed the rapid growth in nutrient loading from the rivers discharging to the northwestern shelf between 1960 and 1990 (Oguz, 2008; Oguz and Velicova, 2010). For phosphorus, growing sources were from urban wastewater, as well as fertilizer application and animal production. For nitrogen it was due mainly to heavy fertilizer application under the centrally planned, Communist economies of Eastern Europe. When Communist states began to collapse in 1989, economies were disrupted and agricultural subsidies disappeared. By 1991, consumption of fertilizers within these watersheds declined by $70 \%$ for phosphorus and $50 \%$ for nitrogen. Nutrient loads discharged by the Danube River dropped over the next few years, particularly for phosphate. It appeared that the extent of hypoxia on the shelf shrank substantially within only 6 years, although it has taken a longer time for the benthic communities to recover (Mee, 2006).

This story of Black Sea ecosystem recovery has been frequently cited as demonstration of the fairly rapid coastal response to a significant decrease in nutrient inputs to a large watershed. More recent analysis employing models of hypoxia formation and persistence matched with available observations (Capet et al., 2013) suggests that recovery is more prolonged than projected by Mee (2006), who had only limited observations during the recovery period. The models suggest that hypoxia has not been reduced as much as suggested. Although hypoxia was less extensive in 2009 than in 1987, it expands with warmer sea surface temperatures. The accumulation of organic matter in sediments introduces important inertia in the recovery process under declining enrichment, having an effect for as long as 9 years. The inertia in the benthic system may be more complex than just organic matter storage and entails recovery of the functions of biological communities, making resilience in response to disturbances difficult to recover once lost.

In 1992 the six Black Sea countries ratified the Convention on the Protection of the Black Sea Against Pollution (Bucharest Commission) and in 1996 adopted the Strategic Action Plan 
for the Rehabilitation and Protection of the Black Sea, which was updated in 2009. The Bucharest Commission developed common strategic goals with the International Commission for the Protection of the Danube River, including avoiding exceeding the nutrient loads experienced during the mid-1990s. Two of the littoral nations, Bulgaria and Romania, and most of the nations in the Danbue watershed are members of the European Union and thus are responsible for implementing the EU directives (O’Higgins et al., 2014).

Achieving the nutrient load exceedance goal, much less additional load reductions, is highly problematic for several reasons. Monitoring of nutrient concentrations and loads is limited and inconsistent, even the benchmark 1990s load levels are poorly defined (Strokal and Kroeze, 2013). Furthermore, there is no formal allocation of loading limits among the catchments and nations on which to target abatement actions. The Danube catchment supplies $70 \%$ of the nutrient loads to the northwestern shelf. There $86 \%$ of the nitrogen emissions and $71 \%$ of phosphorus emissions now come from diffuse sources, but expenditures to reduce eutrophication go overwhelmingly to improve wastewater treatment (O'Higgins et al., 2014). While the EU member nations within the catchment are expected to comply with E.U. environmental directives, they also receive agricultural subsidies that increase fertilizer use and intensify animal production. The EU directives have not demonstrated the ability to improve agricultural practices at the spatial scales required to address diffuse pollution, leaving it to each member state to define and address unclear requirements. Furthermore, Black Sea nations have very different economic conditions, languages, culture and traditions all within a region of great geopolitical tension, further exacerbating the scale mismatch in environmental management.

\section{NORTH AMERICA}

Many estuaries, bays and shallow continental shelf environments in the United States experience eutrophication, particularly along its east and Gulf coasts (Bricker et al., 2008). Here I examine the eutrophication abatement efforts in only three of those ecosystems because of their large scale, the concerted management efforts specifically directed at abating eutrophication, and illustrative range in the dominance of point versus non-point sources. Many bays and estuaries are included within the US Environmental Protection Administration's (USEPA) National Estuary Program (NEP). There are now 28 so designated, notably excluding the Chesapeake Bay that has its own federal authorization. Each NEP location has developed a Comprehensive Conservation \& Management Plan that, in most cases, includes a strategy for abating eutrophication. In general, execution of these strategies relies on collaborative rather than regulatory approaches (Lubell, 2004). Few have specific nutrient reduction targets and timelines and governance and accountability mechanisms to track progress.

Even coastal waters such as San Francisco Bay, Puget Sound, and Delaware Bay that were thought not susceptible to eutrophication because of vigorous tidal exchange and mixing are getting a second look. Similarly, Canada's St. Lawrence River estuary, one of the largest in the world, has experienced increased hypoxia, with controversies as to whether this is caused by physical controls (Lefort et al., 2012; Bourgault and Cyr, 2015). However, in no regions of North America has abatement of eutrophication receive more policy and scientific attention that in Tampa Bay, Chesapeake Bay, and the northern continental shelf of the Gulf of Mexico.

\section{Tampa Bay}

Tampa Bay, located on the Gulf of Mexico coast of the Florida peninsula, is an exemplar for successful abatement of coastal eutrophication. Science-based nutrient reduction goals were achieved and desired ecosystem responses occurred (Greening et al., 2014). The bay is a moderately large $\left(1,036 \mathrm{~km}^{2}\right)$ and shallow (mean depth $4 \mathrm{~m}$ ) embayment. Its catchment of $5,700 \mathrm{~km}^{2}$ is $43 \%$ urbanized and experienced dramatic population growth from 0.5 to 1.5 million people between 1950 and 1980. Population growth increased nutrient loads such that by the late 1970s residents and tourists observed the effects of eutrophic decline, including diminished water clarity, accumulations of macroalgae, noxious phytoplankton blooms, and loss of about $50 \%$ of the bay's seagrass meadows. Occasional hypoxia further threatened living resources.

The bay was already phosphorus-enriched because it receives drainage from inland areas mined for phosphorus ore. The ecosystem was and remains strongly nitrogen-limited as indicated by $\mathrm{N}: \mathrm{P}$ ratios and bioassays. Therefore, remediation focused on nitrogen removal from point discharges of sewage and industrial wastes that, in the mid-1970s, comprised $60 \%$ of the total nitrogen load. Political responses at the state and local levels led the way, with the enactment in 1978 of a Florida statute that required advanced treatment for all wastewater treatment plants discharging to Tampa Bay. Additional nutrient limits were required for stormwater discharges beginning in 1985 .

Tampa Bay is included in the NEP and the Tampa Bay Estuary Program (TBEP) has played a critical role in developing an action plan, completed in 1996 and updated in 2006, which has guided the nutrient load reduction efforts. In 1996 the Tampa Bay Nitrogen Management Consortium was created among governmental and industrial organizations to collaboratively allocate additional load reductions needed to meet the targets and offset the effects of continued regional growth. This led to actions to reduce emissions of nitrogen oxides from power plant exhausts, urban fertilizer use restrictions, and other nonpoint source controls of agricultural and mining activities. US federal regulations did not come into play until 1998, when the USEPA recognized a Total Maximum Daily Load (TMDL) based on TBEP-determined targets and Consortiumdetermined allocations.

Under the TBEP, goals and targets were set in a multistep process: (a) a minimum seagrass coverage goal of 15,380 ha, $95 \%$ of that estimated present in the 1950s, was set; (b) light requirements for an important seagrass species, Thalassia testudinum, were determined; (c) water clarity levels needed to assure those light requirements were estimated; (d) maximum chlorophyll $a$ concentrations consistent with the water clarity 

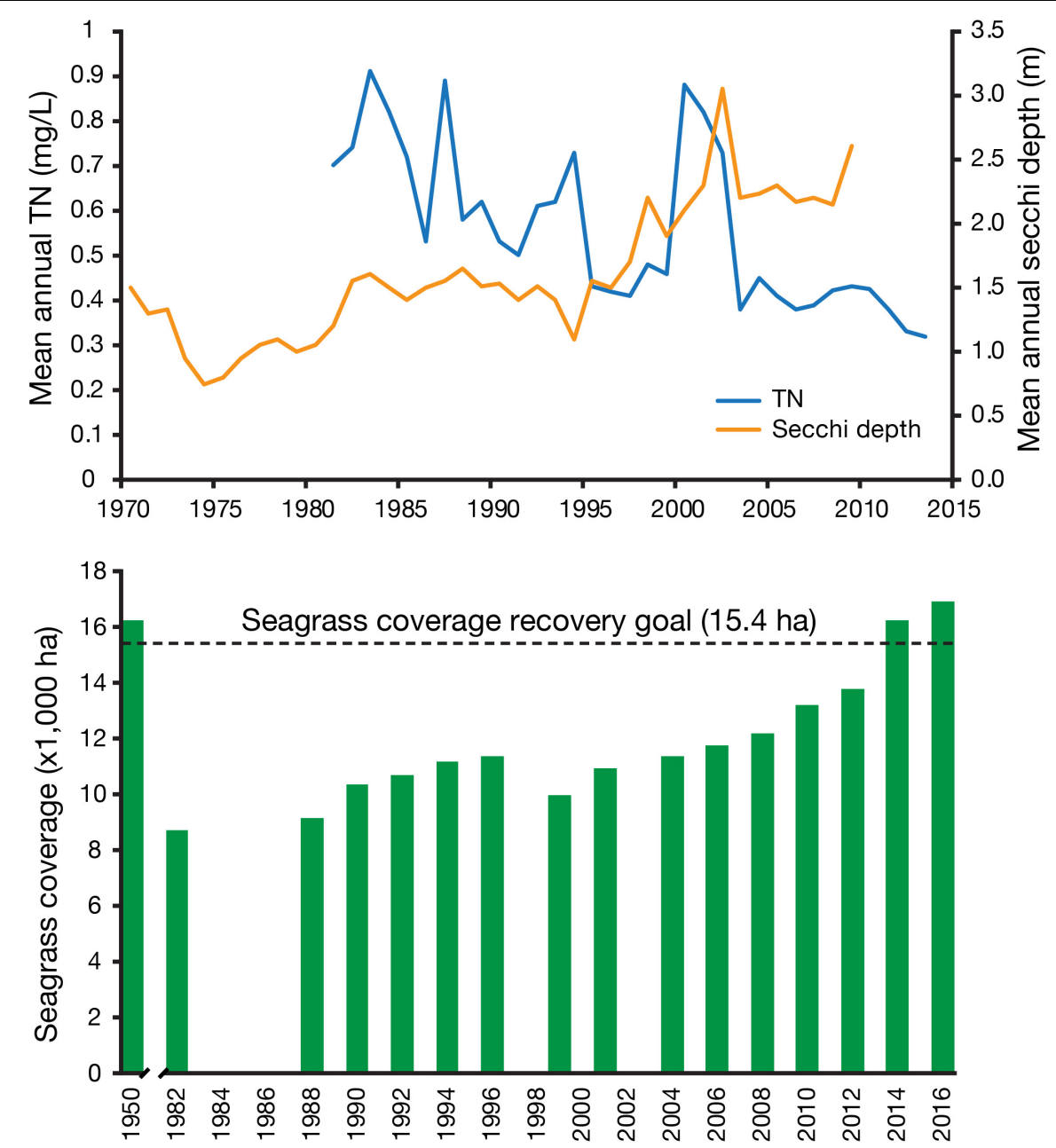

FIGURE 2 | Changes in the mean annual concentrations of total nitrogen (TN) and mean Secchi depth for the middle portion of Tampa Bay, FL, United Sates (top). Extent of seagrass coverage in Tampa Bay (bottom). Modified from Greening et al. (2014) and Sherwood et al. (2016), with permission of Holly Greening and Edward Sherwood.

levels were determined; and (e) maximum nutrient loadings that allow achievement of the chlorophyll a concentration targets were computed. Further, there was a commitment to monitor and assess outcomes and goals annually through an adaptive management processes.

More than US\$500 million has been spent in efforts to reduce nitrogen loadings to Tampa Bay. Loads of total nitrogen during 2000-2011 were 61\% less than in the mid1970 s, predominantly attributable to a $91 \%$ reduction in point source loads. Fertilizer handling losses, although less important, were also significantly reduced and atmospheric nitrogen deposition began to decline after 2000. These load reductions were achieved despite continued rapid growth of the human population to over 2.5 million. Per-capita total nitrogen loads to the bay fell from $9.6 \mathrm{~kg} /$ person $/ \mathrm{yr}$ in the mid-1970s to $1.3 \mathrm{~kg} /$ person/yr for 2000-2011.

TN and TP concentrations in the most affected sections of the bay lagged the load reductions by a few years, ostensibly because of storage of nutrients in sediments, but eventually became two to three times lower than in the early 1980s (Figure 2). Chlorophyll a concentrations declined in a similar manner by about a factor of two, as Secchi depth increased concomitantly. Seagrass expansion followed except after weather anomalies increased nitrogen concentrations in 1998 and setback seagrass expansion. Seagrass expansion continued and exceeded the 15,378 ha goal in 2014 (Sherwood et al., 2016). Within several years of wastewater nutrient load abatement, the ecosystem has returned from a turbid phytoplankton-based state to the clear-water seagrassbased system present in the 1950s. Greening et al. (2014) credited the improvements to development of numeric water quality targets, citizen involvement, collaborative actions, and state and federal regulatory programs. Additionally, Sherwood et al. (2016) emphasized the importance of long-term monitoring for measuring progress and thus sustaining political and societal will to continue actions and investments.

Recovery of seagrass beds also occurred following reductions in nitrogen loading to other smaller bays nearby along the Florida Gulf (Tomasko et al., 2018). Seagrass coverage within 
the region increased by 12,171 ha between the 1980s and 2016, even with heavy human development along the shorelines and within the catchments. Abatement of eutrophication in other coastal waters of Florida has proven much more recalcitrant. In particular, worsening eutrophication is evident in bays and estuaries south of the Tampa Bay region that receive drainage from the greater Everglades ecosystem. In order to manage flooding in heavily populated areas in southeastern Florida, large quantities of water that naturally flowed through the Everglades from Lake Okeechobee, situated in the center of the Florida peninsula, are diverted to both coasts into the St. Lucie Estuary on the Atlantic coast (Kramer et al., 2018) and the Caloosahatchee River estuary on the Gulf of Mexico coast (Heil et al., 2014). These flows deliver large loads of nutrients from agricultural lands north of the lake or from internal phosphorus loads within the lake. Diversion of excess water through the St. Lucie estuary stimulates blooms of cyanobacteria and has reversed water quality improvements and seagrass recovery in the adjacent Indian River Lagoon. For the Caloosahatchee estuary, nutrient diversions may be intensifying or prolonging red tides, blooms of the toxin-producing dinoflagellate Karenia brevis, in bays and along the coast. Nutrient source controls, even if effective, would likely not produce results in the estuaries for decades. Increasing the capacity of stormwater treatment areas within the agricultural regions south of the lake faces practical limitations and high costs (Wetzel et al., 2017). Moreover, this would not address the reduction of nutrient losses at their source. Meanwhile, scientific debates about the role of nutrient inputs from lower Everglades as causes of blooms of cyanobacteria and algae in Florida Bay continue (Shangguan et al., 2017).

\section{Chesapeake Bay}

With tidal waters extending over $11,600 \mathrm{~km}^{2}$, the Chesapeake Bay is 11 times larger than Tampa Bay, but 32 times smaller than the Baltic Sea. Its $166,000 \mathrm{~km}^{2}$ catchment is, on the other hand, only 10 times smaller than the Baltic and 29 times larger than Tampa Bay, illustrating why, with it $<1 \mathrm{~m}$ tidal range and 6-month mean residence time, it is highly susceptible to changes in delivery of nutrients from diverse land-based sources. The Chesapeake Bay has long been the focus of research related to eutrophication (Kemp et al., 2005). In the 1950s efforts focused on reducing organic waste discharges from Washington, D.C., at the head of the tidal Potomac River, one of the major tributaries discharging to the bay. When noxious algal blooms continued after the completion of secondary treatment, additional phosphorous removal from wastewater discharges was begun in 1974 and fully implemented by 1986 .

In 1972 Tropical Storm Agnes resulted in record flows in virtually all the major rivers discharging to the Chesapeake Bay. Recovery from the effects of the massive freshet was slow with a lingering reduction in water clarity, more pervasive hypoxia in bottom waters, and seemingly permanent loss of submersed vascular plants over a large extent of the bay and its tidal tributaries. A 5-year study was commissioned that suggested large-scale eutrophication was the underlying culprit. Still, there were often passionate scientific debates as to whether, for example: hypoxia was primarily driven by stratification during high river discharge or by anthropogenic nutrient inputs; submersed vegetation was lost because of the expanded use of agricultural herbicides or eutrophication; and nitrogen loads played any role or if controlling phosphorous alone was sufficient (Kemp et al., 2005). Results of the 5-year study prompted the first Chesapeake Bay Agreement in 1983 among three states (Pennsylvania, Maryland and Virginia), Washington, D.C., and the federal government, thus establishing the Chesapeake Bay Program (CBP). The agreement simply committed the parties to collaborate to improve and protect the water quality and living resources. It was not until 1987 that the parties committed to develop and implement a strategy to achieve at least a $40 \%$ reduction of nitrogen and phosphorous entering the mainstem of the Chesapeake by the year 2000. The scope and timing of the committed nutrient load abatement was remarkably similar and coincident with the HELCOM and OSPAR plans for the Baltic and North seas.

Setting the initial $40 \%$ nutrient reduction was based on simple models available at the time and general estimates of what would be effective and achievable (Boesch et al., 2001). In developing the strategy it was realized that nutrients emanate from states in the catchment not then party to the agreement and from atmospheric sources not subject to water pollution controls. Limited to controllable inputs, the total load reductions sought were actually about $24 \%$ of the nitrogen and $35 \%$ of the phosphorus total loads. The agreement specified that load reductions would be "equitably" allocated among the jurisdictions and these allocations were made in 1988. Each state voluntarily set out to achieve their assigned nitrogen and phosphorus load reductions.

As 2000 approached it was clear that the programs put in place fell woefully short of what was needed to achieve the committed load reductions. A broader and bolder agreement was adopted that required a technically more sophisticated determination and allocation of nutrient load reductions sufficient to achieve water quality standards for designated used in various parts and depth zones in the bay. The new approached linked "airshed" (for atmospheric deposition), watershed, and estuarine ecohydrodynamic models (Linker et al., 2013). The new targets called for reduction in loads of nitrogen and phosphorus of about $43 \%$ from 1985 baseline levels (actually a 5-year hydrological average) by the year 2010 .

The voluntary approach was continued, but recognizing that it might again fall short, the Chesapeake agreement parties, which included the three additional states that partially lie in the bay's catchment, subsequently agreed that should they fall short they would develop and implement a Total Maximum Daily Load or TMDL plan, which they would be legally bound to meet. Somewhat analogous to the European Union's Water Framework Directive in intent if not process, section 303(b) of the US Clean Water Act requires that for "impaired waters" in which technology-based regulations are not stringent enough to meet the water quality standards set by the states, a TMDL must be calculated as the maximum amount of a pollutant that can be put in a water body and still meet water quality standards. States are then legally responsible through voluntary or regulatory programs to reduce the pollutant loading to the level of the TMDL. While the Clean Water Act prohibits the USEPA from 
regulating agricultural runoff other than from combined animal feeding operations, the states could put in place statutes and regulations to control such non-point source pollution.

When it was apparent that they would fall well short of the 2010 target, the parties began to formally develop the TMDL plan, issued by the USEPA in December 2010. The plan refined allocations of load reductions to be met by 2025 and requires reporting and evaluation at 2-year milestones. USEPA's options if a state falls short of its legal obligations are fairly weak, including revocation of delegated authority for permitting point-source discharges and loss of federal grant support. Within weeks of its issuance, the American Farm Bureau Federation, joined by other agricultural business organizations, filed suit in federal court to halt the implementation of the Chesapeake TMDL on the grounds that it was not lawful in providing detailed allocations of load reductions, requiring reasonable assurances, and mandating states to address water quality impairment not just in that state but also in downstream states. The suit also alleged that the TMDL relied on overextended scientific models and flawed data. It was clear from the plaintiff's arguments that their primary goal was to avoid a precedent that could be applied to the much larger agricultural enterprise in the Mississippi River basin. The federal court upheld the legality of the Chesapeake TMDL and the Farm Bureau's appeal of the court's decision was denied.

Estimated annual nutrient loads to the bay are depicted by source category and period in Figure 3. Loads at the end of 2016, the mid-way point in the implementation of the binding TMDL, are compared with the starting baseline ca. 1985, prior to the implementation of the TMDL in 2009, and reaching the TMDL by 2025 . While direct measurements of wastewater loads are included in these estimates, other loads are estimated by watershed model simulation for hydrological conditions consistent with the base condition around 1985 . For any given year, the loads could be greater or lower than those loads depending on the annual freshwater discharge that can vary by a factor of three. Furthermore, in order to guide implementation, source reductions assumed for diffuse source abatement practices are immediately credited as load reductions in the watershed model. This adds uncertainty associated with assurance of actual implementation and presumed efficiency of the practice, as well as lag times between implementation and realized load reductions to the bay.

On the basis of the modeled estimates, the CBP concluded that by 2017 actions had been taken that would reduce phosphorus loads nearly to the TMDL target, largely because wastewater treatment had already exceeded the load reductions allocated for that sector. Agricultural loads of phosphorus had been reduced by $69 \%$ of the TMDL planning target, but little reduction in loads from urban runoff had yet been achieved, mainly because land development had continued to expand. The watershed model may have underestimated phosphorous loads from soils with a large phosphorus surplus due to repeated application of manures (Kleinman et al., 2011).

For nitrogen, loads from wastewater have been reduced below the 2025 allocation because of substantial investments in enhanced nitrogen removal, largely funded by user fees. Controls on nitrogen oxide emissions from power plants and vehicles through implementation of the U.S. Clean Air Act substantially reduced atmospheric deposition such that this could account for most of the observed decline of nitrate fluxes in the Potomac River catchment (Eshleman and Sabo, 2016). On the other hand, simulated nitrogen load reductions from agriculture, urban runoff and septic disposal of domestic wastes are significantly behind schedule. Practices have been implemented to meet only $18 \%$ of the load reductions allocated to agriculture under the TMDL plan, despite substantial financial support, technical assistance and state regulations for nutrient management. While the watershed model estimates that the practices put in place since the 1985 should reduce nitrogen loads from agriculture by $25 \%$, loadings delivered to the bay from its major rivers have not declined comparably and those draining heavily agricultural areas not at all (Zhang Q. et al., 2015). This indicates either that delivered load reductions lag for a decade or more due to groundwater storage or that management actions have been less effective than credited, or both. Even so, at the end of 2016 estimated nitrogen load reductions from agriculture were behind schedule in each state, but particularly in Pennsylvania, which occupies $35 \%$ of the bay's total catchment but has no bay shoreline.

In addition to new Watershed Implementation Plans for each jurisdiction designed to close the gap to the 2025 targets, the $\mathrm{CBP}$ is developing strategies to offset the additional nutrient load that has resulted from the sediment infilling of pools behind hydroelectric dams along the lower Susquehanna River (Zhang et al., 2016), the large tributary river discharging to the head of the Chesapeake Bay. The Program is also estimating what additional nutrient load reductions would be required to maintain dissolved oxygen standards under the changing climatic changes (principally warmer estuarine temperatures and increased runoff; Irby et al., 2018) that will have occurred between 1985 and 2025 .

Beyond the CBP watershed model estimates (Figure 3), monitoring of wastewater discharges and rivers draining to the bay demonstrates overall abatement of nutrient loading, much of it evident prior to the imposition of a TMDL in 2010. Yet, until recently there were few signs of the anticipated responses of the estuarine ecosystem. Murphy et al. (2011) were the first to document the reduction in late summer hypoxic volume beginning in the 2000s. Gurbisz and Kemp (2014) chronicled the rapid reestablishment in the early 2000s of a large submersed plant bed near the head of the estuary that had virtually disappeared in 1972. More recently, Lefcheck et al. (2018) showed that coverage by submersed vascular plants throughout the bay increased 17,000 ha since 1985, reaching a level not seen in a half century. They attributed this to a $23 \%$ decline in dissolved nitrogen concentrations. Testa et al. (2018) reported a decline in $\mathrm{NH}_{4}$ and an increase in $\mathrm{NO}_{2+3}$ concentrations in channel bottom waters during late summer as dissolved oxygen concentrations have increased, suggesting a vicious biogeochemical cycle may be breaking (Kemp et al., 2005). Zhang et al. (2018) demonstrated progressive improvement in a multimetric index of water quality attainment that integrates dissolved oxygen, water clarity, submersed vascular vegetation and chlorophyll $a$. This began in 

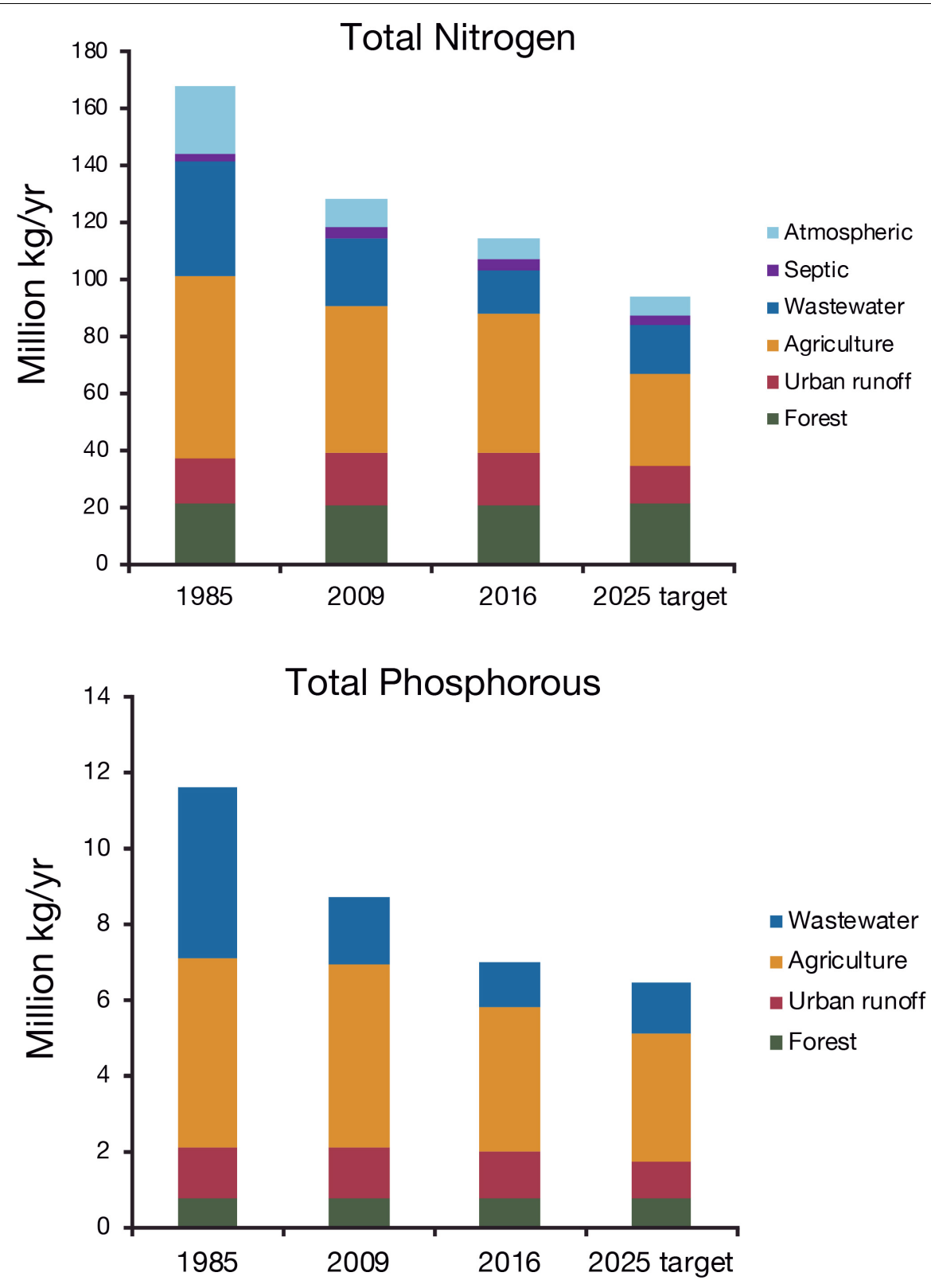

FIGURE 3 | Estimated loading of total nitrogen and total phosphorus to the Chesapeake Bay, United States, around 1985 (before the campaign to reduce nutrient loads), 2008 and 2016 compared to the Total Maximum Daily Load targets to be achieved by 2025. Based on Phase 5.3.2 watershed model and derived from https://www.chesapeakeprogress.com/clean-water/watershed-implementation-plans; accessed on 12 February 2019.

the late 1990s following wastewater treatment plant upgrades and reductions in atmospheric deposition of nitrogen.

While the intended rehabilitation of the Chesapeake Bay is far from completed, high-level, intergovernmental commitment has been sustained for more than 35 years and demonstrable nutrient load reductions have been accomplished. More reductions in nutrient loads will be required and it remains to be seen if they will be accomplished by the third deadline in 2025 and, if not, what will be the legal and political repercussions. Even then, it may take decades for the full rehabilitation of the ecosystem to be realized. Changes in climate and in socioeconomic drivers will also influence outcomes. But, it is too soon to confine the rehabilitation goals for the Chesapeake to Neverland status (sensu Duarte et al., 2009).

\section{Northern Gulf of Mexico}

Bottom waters over the inner continental shelf of the northern Gulf of Mexico near the Mississippi River delta experience recurring seasonal hypoxia, the first large area of coastal hypoxia to which the term "Dead Zone" was applied. Until the mid1980s hypoxia was sparingly observed and thought to be isolated, ephemeral and natural (Rabalais et al., 2002). Compelling 
evidence grew that expansive and seasonally persistent hypoxia had occurred after the 1960s coincident with a three-fold increase in the nitrate loads from the Mississippi and Atchafalaya rivers, the two principal distributaries from the 3.2 million $\mathrm{km}^{2}$ river basin (Rabalais et al., 2007). Based on mid-summer, quasi-synoptic surveys conducted since 1985, bottom hypoxia (dissolved oxygen concentrations $<2 \mathrm{mg} / \mathrm{L}$ ) has extended over an area averaging $13,700 \mathrm{~km}^{2}$ and as much as $23,000 \mathrm{~km}^{2}$, typically in water depths of 10-40 m. The extent depends on the amount and timing of river discharge, prevailing winds and the occurrence of early tropical storms that mix the water column. Hypoxic conditions usually extend west from the Mississippi river mouth along Louisiana to the upper Texas coast. Annual surveys underestimate the extent of bottom hypoxia as it can form, dissipate and move throughout the summer.

Seven years after the first suggestions that the extensive shelf hypoxia likely resulted from increased nitrate loading from the Mississippi River (Turner and Rabalais, 1991), the US Congress enacted the Harmful Algal Bloom and Hypoxia Research and Control Act of 1998 (HABHRCA). The Act required the submission of an integrated assessment of northern Gulf hypoxia that examined its distribution, dynamics and causes; ecological and economic consequences; sources of nutrient loads; and methods, costs and effects of reducing these loads. That assessment was published in 2000 and an Action Plan was endorsed the next year by the interstatefederal Mississippi River/Gulf of Mexico Watershed Nutrient Task Force (Rabalais et al., 2002). The assessment concluded that hypoxia in the northern Gulf of Mexico is caused primarily by increased nitrogen delivered from the Mississippi-Atchafalaya River Basin in combination with the natural stratification of Gulf waters. Nitrate flux nearly tripled between the 19551970 and 1980-1996, while organic carbon and phosphorus fluxes probably decreased over the latter 20th century. Ninety percent of the nitrate load came from diffuse sources, principally agricultural lands in Iowa, Illinois, Indiana, southern Minnesota, and Ohio, 1,800 km or more upstream of the Gulf of Mexico. An approximately $40 \%$ reduction in total nitrogen flux would be necessary to return to loads comparable to those during 1955-1970, requiring limiting losses from fields and enhancing nitrogen retention and denitrification within the basin.

The goal of the 2001 Action Plan was to reduce the 5-year running average extent of the Gulf hypoxic zone to less that $5,000 \mathrm{~km}^{2}$ by 2015 through implementation of specific, practical, and cost-effective voluntary actions to reduce the discharge of nitrogen. It did not commit to a specific reduction in nitrogen discharge, but recognized that a $30 \%$ nitrogen load reduction was probably needed. The Plan proved controversial to upstream agricultural interests, so in 2006, as part of a planned 5-year reassessment, a new panel was convened under the auspices of USEPA's Science Advisory Board to evaluate more recent science and options for reducing the size of the hypoxic zone. The USEPA took the unusual step of inviting public comment on the scientists being considered for the panel and then deciding not to appoint any of those who had been involved in the 2000 integrated assessment. Nonetheless, the panel reaffirmed the principal conclusions of the integrated assessment
(EPA Science Advisory Board, 2008). It found the $5,000 \mathrm{~km}^{2}$ goal a reasonable endpoint, but noted that it would not likely be achieved by 2015 because of limited progress in implementing policies, programs and strategies to reduce nutrient loads and lag times in ecological system response. The panel recommended the reduction in both nitrogen and phosphorus fluxes by at least $45 \%$.

The Task Force has continued to meet regularly over the 18 years since developing the Action Plan. It is presently comprised of representatives of five federal agencies and 12 states within the Mississippi River Basin. Its members are federal officials at the assistant secretary level or below and department heads or below from the states. Notably, officials from the departments of agriculture represent most of the states responsible for large agricultural nutrient loads-Iowa, Indiana, Illinois, and Ohio-rather than environmental protection or natural resources department heads.

After the reassessment, the Task Force produced the 2008 Gulf Hypoxia Action Plan that identified actions to accelerate the reduction of nitrogen and phosphorus losses and advance the science, track progress and raise awareness. Following another reassessment in 2013, the Task Force decided to maintain the goal of reducing the hypoxic zone to less than $5,000 \mathrm{~km}^{2}$, but extended the target date 20 years to 2035. The Task Force set an interim 20\% reduction target for both nutrients by 2025 as a milestone for immediate planning and implementation actions. Once again, it allocated no specific nutrient load reductions to states or sub-basins. States were expected to complete and implement comprehensive nitrogen and phosphorus reduction strategies. These were completed between 2013 and 2016, but vary in designation of specific nutrient load reduction targets and geographical targeting of technical and financial assistance for reducing agricultural nutrient losses. Both the states and the USEPA have contested lawsuits seeking enforceable limits on nitrogen and phosphorus pollution through the preparation and implementation of a TMDL and resisted the development of numeric water quality criteria for nitrogen (Sigford, 2016). Even the state of Louisiana, the most affected by Gulf hypoxia, has resisted designating seasonally hypoxic shelf waters as "impaired," as this might initiate a TMDL process.

Resistance to allocating and targeting nutrient loss abatement has limited progress despite the results of effective semiempirical modeling tools that locate and quantify the sources of nitrogen and phosphorus loads delivered to the Gulf of Mexico (Robertson and Saad, 2014). Delivered nitrogen sources are highest from the Corn Belt centered over Iowa and Indiana, but the highest phosphorus yields are associated more with animal agriculture and wastewater treatment discharges. Models have even been used to target the specific subwatersheds where existing cropland conservation practices augmented by better fertilizer management could achieve the hypoxia reduction goal most cost-effectively (Rabotyagov et al., 2014).

More recent estimates of the effects of nutrient load reductions on the extent of shelf hypoxia have ranged from relatively linear production-respiration models to more complex threedimensional hydrodynamic models (Fennel et al., 2016; Scavia et al., 2017). Some models suggest that nitrogen loads would 
have to be reduced as much as $60 \%$ to accomplish the $5,000 \mathrm{~km}^{2}$ maximum hypoxia areal extent goal. If both nitrogen and phosphorus loads were reduced simultaneously, a $48 \%$ reduction in each would be required. Benchmarking the goal by hypoxic volume rather than aerial extent, as is done for the Chesapeake Bay, may be more relevant to living resource impacts. A more modest $25 \%$ nitrogen load reduction would substantially reduce the thickness of the hypoxic layer to a relatively thin layer near the bottom in much of the affected area (Scavia et al., 2019).

Because it its complexity and the economic stakes, science underpinning the abatement of Gulf hypoxia has attracted its critics. During the initial integrated assessment, scientists aligned with agricultural interests or supported by the fertilizer industry challenged the basic conclusion that shelf hypoxia had worsened as a result of increased nitrogen loading from the MississippiAtchafalaya Basin (Rabalais et al., 2002). Some oceanographers argued that shelf hypoxia was caused by upwelling, stratification from increased river flow, or increased loading of terrestrial organic matter (e.g., Rowe and Chapman, 2002). A USEPA analyst blamed hypoxia on phosphorous pollution from industry and cities and asserted little would be accomplished by reducing nitrogen loads (Ferber, 2004). A member of the USEPA Science Advisory Board panel, joined by other regional scientists, criticized what they termed the "nutrient-centric view" of hypoxia abatement, stating that "mandating a specific nutrient reduction target level is "difficult to defend" and "doomed to fail" (Bianchi et al., 2008, 2010). They asserted that the goal of reducing hypoxia to $5,000 \mathrm{~km}^{2}$ was scientifically unjustified and expressed doubt that reducing nutrient loads would contract hypoxia occurring west of the Atchafalaya River. Further, these authors suggested worsening hypoxia could have been caused by outflowing organic matter from deteriorating coastal wetlands.

Scientists experienced with eutrophication and hypoxia in the Gulf and elsewhere countered these criticisms (Boesch, 2003; Boesch et al., 2009). Furthermore, subsequent research using mass balances (Das et al., 2011) and stable isotopes (Wang et al., 2018) demonstrated that inputs of wetland organic carbon could have only a trivial effect on shelf hypoxia. Recent models have also indicated that the hypoxic volume on shelf west of the Atchafalaya would be substantially ameliorated by reductions of riverine nutrient loads (Scavia et al., 2019). While legitimate scientific debates are appropriate and often helpful, the aforementioned criticisms of reliance on nitrogen source abatement cast doubts that slowed Task Force actions at critical intervals. Criticisms also inspired an attempt in the U.S. Congress in 2014 to amend HABHRCA to prevent any further work on the Action Plan until another assessment was conducted to address the issues raised by Bianchi et al. (2008). The paralyzing effects of such controversies illustrate the need for more effective mechanisms to resolve scientific questions concerning important matters of public policy in a timely fashion.

Despite hundreds of meetings, state reduction plans, and substantial federal state and private expenditures for improvements in nutrient management practices over the past 17 years of the Action Plan, there is no evidence that nutrient loads to the Gulf or hypoxia have yet been reduced. The extent of hypoxic bottom waters mapped in the 2017 was $22,770 \mathrm{~km}^{2}$, the largest ever measured. The 5-year running average was essentially the same as at the starting point for the Action Plan. Nutrient loading varies widely from year-to-year as a function of river flow, so that even 5-year averages of loads can be misleading. Once normalized for variations in flow by statistical adjustment for time, discharge and season, neither riverine nitrate concentrations nor loads showed any decline between 1985 and 2010 (Sprague et al., 2011; Murphy et al., 2013). Flow-adjusted nitrate loads have been essentially stable since 1995 (Figure 4), in contrast with declining flow-adjusted loads to the Chesapeake Bay (Oelsner and Stets, 2019).

The lack of a significant decline in nitrate loading does not necessarily mean that actions taken for more efficient use and retention of agricultural nutrients have been ineffective. Flowweighted nitrate concentrations in the Illinois River catchment declined significantly since 1990 due to increasing nitrogen use efficiency in largely tile-drained agriculture and the depletion of legacy nitrogen, resulting in a $10 \%$ load reduction (McIsaac et al., 2016). However, loads did not decline significantly in other watersheds in the Basin and increased in the Upper Mississippi and Missouri rivers (Murphy et al., 2013). Nitrate loads from the Iowa, contributing about $29 \%$ of loads to the Gulf, have been increasing since 1999 (Jones et al., 2018). Nitrogen use efficiency in the agricultural heartland was already high by global standards and has shown only small decline (Swaney et al., 2018), but the area under cultivation has expanded, largely as a result of the dramatic increase in crops grown not for human food or animal feed, but for biofuels. Federal requirements for the inclusion of ethanol and biodiesel in motor fuels have driven the expansion and focus of cropping, with $40 \%$ of the maize crop currently produced to refine ethanol. Increased production of maize would likely increase nitrate export to the Gulf by 14\% between 2002 and 2022, while improved crop nitrogenrecovery efficiency (NRE) and reduction in atmospheric nitrogen deposition could result in only a 9\% reduction (McCrackin et al., 2017). Significant nitrogen load reductions will require aggressive actions to improve basin-level NRE and remove nitrogen from wastewaters. Practices that reduce nitrogen losses from tile-drained cropland, responsible for up to half of nitrate export, would also have substantial benefit. Greater reliance on perennial grasses rather than maize for bioenergy development could also substantially reduce nitrogen and phosphorus loads, particularly if these crops were strategically placed as buffers between streams and intensively fertilized food crops (Ha et al., 2018).

It should be expected that reduction of nutrient fluxes from the Mississippi and Atchafalaya rivers lags the actions taken to reduce their losses from crop production because of temporary storage in soils, groundwater and streams. These lags could delay delivered load reductions for years to decades. Employing a model that accounts for such memory effects of past nutrient use, Van Meter et al. (2018) estimated that even if agricultural nitrogen use became $100 \%$ efficient, it would take decades to achieve a $60 \%$ reduction. More effective management of tile drainage and restoration and reconnection of wetlands and bottomland forests could speed up the process by enhancing denitrification and nutrient retention. 

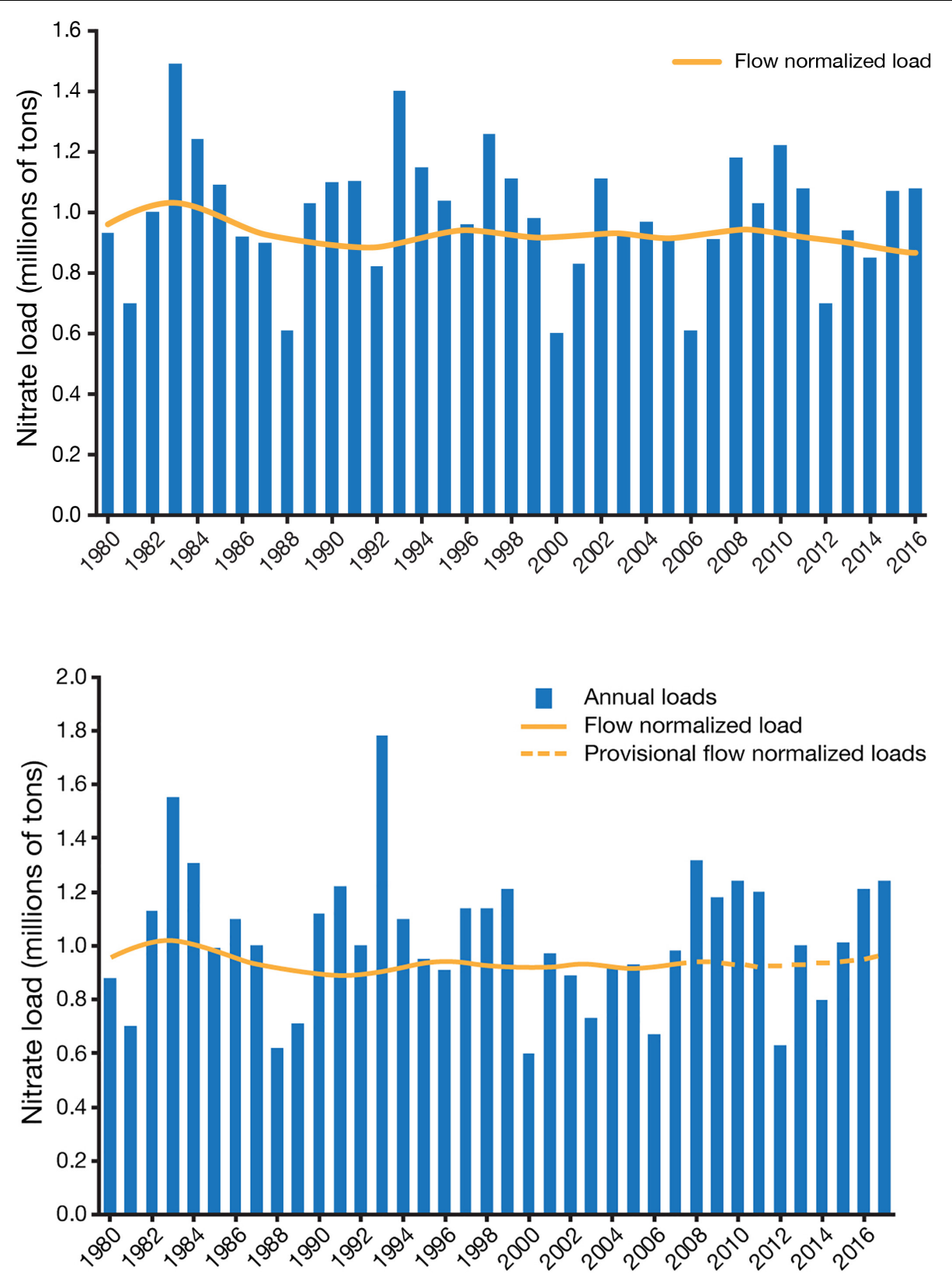

FIGURE 4 | Annual nitrate loading to the Gulf of Mexico from the Mississippi-Atchafalaya River Basin compared to the flow-normalized load based on weighted regressions on time, discharge and season, using methods described by Sprague et al. (2011). Modified from https://nrtwq.usgs.gov/mississippi_loads/\#/GULF; accessed on 12 February 2019. Loading estimates produced by Lori Sprague and Casey Lee, U.S. Geological Survey.

\section{ASIA}

With its large and dense populations and rapidly increasing demand for animal protein, the coastal waters of Asia experience widespread and generally increasing eutrophication. While efforts were made to abate eutrophication in Japan and Hong Kong decades ago, scientific documentation of eutrophication in much of the rest of Asia has emerged just during the last two decades as there yet are few concerted efforts to abate coastal eutrophication.
In Japan, coastal eutrophication has been manifest mainly in bays such as Tokyo and Ise Bays and in portions of the Seto Inland Sea that are surrounded by large human populations and consequently received heavy loadings of organic matter and nutrients from municipal and industrial wastewaters. In the 1950s extensive red tides in the Seto Inland Sea and fish kills around Tokyo Bay raised concerns about degrading coastal water quality. The Water Pollution Control Law enacted in 1970 required development of effluent and water environmental standards. By 1980 Total Pollutant Load Control Systems 
(TPLCS) were put into practice for Tokyo Bay, Ise Bay and the Seto Inland Sea (Yanagi, 2015). Under this system the Minister of the Environment prepares a Basic Policy for Areawide Total Pollutant Load Control and the Prefecture governors are responsible for formulating and implementing pollutant load control plans. While these plans initially focused on organic pollutant loads, some reductions on nutrient loads were also achieved in the process of abating organic loading. In 2001 total nitrogen and total phosphorus was added as specific reduction targets.

For the Seto Inland Sea, phosphorus and nitrogen loads were reduced by 55 and 45\%, respectively, between 1979 and 2009 , almost all of that attributable to treatment of industrial and domestic wastewaters. Hypoxia has been reduced in heavily impacted waterbodies such as Dokai and Osaka bays, but their rehabilitation has been hindered as a result of large internal sediment loads of phosphorus and deterioration of the physical habitat. Physical restoration and bioremediation are being actively pursued. Red tides in the Seto Inland Sea became less extensive and severe and phytoplankton biomass declined on broader scales. In the Suo Nada, the westernmost portion of the Seto Inland Sea between Honshu and Kyushu, chlorophyll $a$ levels declined substantially, particularly in shallow waters, between 1984 and 2004, closely following reductions in loads of phosphorus and nitrogen (Nishijima et al., 2016). The introduction of advanced treatment for some wastewater discharges has also yielded reductions in nutrient concentrations and chlorophyll $a$ in Tokyo Bay (Kubo et al., 2019). For at least for some Japanese coastal waters, reduced primary production has led to concerns by some fishers, politicians and even scientists that abatement of anthropogenic nutrient loads has been too hasty and has led to severe phosphorus limitation and declines in the secondary production of exploited resources (Yamamoto, 2003).

Based on its experiences in abating eutrophication, Japan has been assisting other East Asian countries in applying TPLCS. Korean coastal waters also experience eutrophication associated with diffuse source runoff and sewage discharges, particularly evident in bays along South Korea's southern coast. This is manifest in seasonal hypoxia (Lee et al., 2018) and harmful algal blooms and red tides (Lee et al., 2013). To abate eutrophication the South Korean Ministry of the Environment has begun to implement the Japanese TPLCS within several catchments.

Efforts have also been undertaken to control the deleterious effects of eutrophication, particularly red tides, in the coastal waters around Hong Kong, a mega-city of 7.4 million people. In the 1980s sewage discharges were redirected from the shallow and poorly flushed Tolo Harbour to the deeper and wellflushed Victoria Harbour (Xu et al., 2010). In 2002 wastewaters discharged to Victoria Harbor were diverted to a new treatment plant that provides chemically enhanced primary treatment and discharges outside of the harbor (Lee et al., 2006). The frequency of red tides, that cause fish kills by depletion of dissolved oxygen rather than by toxins, has been reduced but not eliminated. Controlling excessive nutrient loading presents a complex set of challenges for Hong Kong, which borders on the west to the Zhujiang (Pearl) River estuary that is experiencing emerging hypoxia (Qian et al., 2018). As with the Mississippi, discharges from this large river into the estuary are greatly enriched with nitrogen-nitrate concentrations increased two to three-fold since the mid-1970s, while phosphate concentrations remained constant. Consequently, primary production in the lower estuary is strongly phosphorus limited. During high river flows and when winds drive surface waters to the east, nitrogen-enriched water is driven through Hong Kong's islands to its eastern waters, where production is nitrogen-limited, at least during the summer. This illustrates the complex challenges to management where nutrients are delivered from continental sources interact with those derived from local wastewaters. Fortunately, Hong Kong has sustained a program since 1982 that has monitored water quality and algal blooms and aids researchers in understanding complex dynamics and detecting long-term changes.

Eutrophication is pervasive and worsening along many parts of the coast of China (Jiang et al., 2018), prompting public and media attention, expanded research, and incipient environmental policies. Reminiscent of the Mississippi River and the northern Gulf of Mexico, a zone of seasonally hypoxic bottom water in the East China Sea associated with the plume of the China's largest river, the Chang Jiang, has developed seasonally since at least 1993 (Zhu et al., 2011). This hypoxia is fueled by in situ primary production supported by increased nutrient loads from the river (Wang et al., 2016) that has shifted landward as sediment loads were reduced due to trapping by the Three Gorges Dam (Chen et al., 2017) and extensive tidal flat construction and channelization affected flows from the estuary (Wu $\mathrm{H}$. et al., 2018). So-called green tide blooms of drifting macroalgae (Ulva prolifera) have proliferated along the Yellow Sea coast (Liu et al., 2013), gaining global notoriety when they interfered with sailing events during the 2008 Olympic Games. While expanding seaweed aquaculture within the region apparently seeds these macroalgal blooms, the growth of the drifting green algae is stimulated by anthropogenic nutrient inputs.

In addition to nutrient inputs from populous coastal cities and ubiquitous coastal agriculture and aquaculture, large rivers, including the Huang He (Yellow), Chang Jiang (Yangtze) and Zhujiang (Pearl), drain much of interior China into the Bohai Gulf, Yellow Sea, and East and South China Seas. Between 1970 and 2006 modeled inputs of dissolved nitrogen and phosphorus to these seas increased by a factor of two to five (Strokal et al., 2014). Inputs of particulate nitrogen and phosphorus and dissolved silica declined due to damming of rivers, notably the construction of the Three Gorges Dam on the Chang Jiang. As opposed to the recently declining or stable nutrient loads from large rivers in Europe and North America, nitrogen and phosphorus discharges monitored from the eight main rivers flowing into the coastal waters of China increased by 40 and $75 \%$, respectively, from 2006 to 2012 (Tong et al., 2015). While nearly half of the dissolved nitrogen and virtually all of the dissolved phosphorus loads to the Bohai Gulf in 2000 originated from human sewage, almost all of the dissolved nitrogen and nearly half of the dissolved phosphorus inputs to seas to the south emanate from agricultural sources or, in the case of nitrogen, atmospheric deposition (Strokal et al., 2014). Development scenarios for 2030 to 2050 suggest that it will be difficult to 
hold the line on, much less reduce, nitrogen and phosphorus loads. Improved sewage treatment is required to reduce risks of harmful algal blooms in the Bohai Gulf, but improved agricultural management is required elsewhere. Given the demands for agricultural production in China, achieving more efficient use of fertilizers will require fundamental restructuring of Chinese agriculture by increasing farm size (Wu Y. et al., 2018).

While long experiencing eutrophication of restricted coastal waters, the Indian subcontinent, with its dense and growing populations and developing economies, is also increasingly susceptible to regional-scale eutrophication. Models similar to those discussed for China estimate that dissolved nitrogen and phosphorus loads discharged to the Bay of Bengal doubled between 1970 and 2000 (Sattar et al., 2014). While the load increases emanated primarily from fertilizers and manure, the contribution of nitrogen and phosphorus from human wastes, much of which is not collected or treated, is likely underestimated (Amin et al., 2017). With economic and social development projected to increase, constraining the increase in nutrient loads will require more efficient use of fertilizers and manure and recycling sewage wastes in agriculture (Sattar et al., 2014).

\section{AUSTRALIA}

Eutrophication in coastal waters of the more sparsely populated and mostly arid Australia has been evident principally in a few bays and estuaries (Davis and Koop, 2006). Cyanobacterial blooms created nuisances in the Peel-Harvey estuary, south of Perth, beginning in the 1960s. Creating a second channel entrance from the restricted estuary to the ocean in 1994 alleviated the nuisance blooms. Concomitant reductions in phosphorous loading may have also played a role.

Moreton Bay, near Brisbane, is impacted by runoff and deposition of fine-grained sediments from rivers and nutrients discharged by wastewater treatment plants. In the late 1990s local governments began to implement advanced wastewater treatment, specifically including nitrogen removal (Abal et al., 2001). By 2011 nitrogen and phosphorus discharged in wastewater declined by 65 and 46\%, respectively (Gibbes et al., 2014). By 2012 seagrasses that had largely disappeared from the mainland shore of the bay had returned to some extent. Nonetheless, the scientific justification for nitrogen removal-isotopic indicators indicating biological uptake of sewage-derived nitrogen and nutrient addition bioassays (Glibert et al., 2006)—was questioned by Wulff et al. (2011). They argued that there is ample benthic nitrogen fixation such that phosphorus is effectively the limiting nutrient in Moreton Bay. They suggested that reducing nitrogen loads exacerbated blooms of the nitrogen-fixing harmful cyanobacterium Lyngbya majuscule, although others pointed to bioavailable iron in humic runoff as the principal driver of these blooms (Albert et al., 2005). Local authorities have not relaxed advanced nutrient removal wastewaters.

In an arm of the Hawkesbury River estuary north of Sydney, Larsson et al. (2017) followed the response of phytoplankton after the implementation of nitrogen removal in a wastewater effluent using a long-term monitoring database. The concentrations of oxidized nitrogen and ammonia declined in the estuary and chlorophyll a concentrations also declined during the summer months, when the risk of harmful algal blooms is greatest.

While these examples from Australian coastal waters are from relatively enclosed waters mainly affected by wastewater discharges, a much larger challenge confronts the abatement of land-based nutrient pollution of the Great Barrier Reef (GBR) and the broad lagoon separating it from the mainland (Kroon et al., 2016). The area at risk is vast-the GBR Marine Park alone covers $344,400 \mathrm{~km}^{2}$ - and the excess nutrients emanate predominantly from agriculture in areas lightly populated by humans. Changes in this coastal ecosystem began with extensive land clearing of catchments after 1850, but have become more profound with the intensification of agriculture, including widespread cattle grazing and more concentrated dryland cropping and irrigated production of sugar cane and fruit. As elsewhere, use of fertilizer nitrogen increased dramatically after the 1950s, and loads of nitrogen and phosphorus to the coastal marine system increased many-fold. Increased nitrogen availability resulted in higher phytoplankton biomass, which is associated with outbreaks of the coral-eating crown-or-thorns seastar. In addition, macroalgae proliferated on inshore reefs, crowding out corals, and fine sediments and nutrients led to reduced water clarity and loss of seagrass beds. To be sure, eutrophication is not the cause of the massive die-off of corals on the northern Great Barrier Reef due to recent bleaching induced by extremely high temperature (Hughes et al., 2018), but it contributes additional stress, particularly to inner shelf reefs.

In 2003 the Australian and State of Queensland governments jointly began to implement a Reef Water Quality Protection Plan that relies predominantly on the use of voluntary best management practices for agricultural land uses. Nearly AUS\$1 billion will have been spent through 2022 to implement the plan. However, other government policies allowing further development of water resources in order to increase agricultural production actually work against the adoption and effectiveness of these best practices. Models developed as part an integrated monitoring, modeling and reporting program suggest some progress was made toward the meeting the 2013 nutrient load reduction goals. Still, the estimated load reductions fell short because disincentives and perceived risks limited the sustained application of best management practices. Even if these practices had been fully and successfully implemented they would be insufficient to achieve nutrient load reduction goals.

As with the controversy concerning limiting nutrients in Moreton Bay, assessments of eutrophication status and solutions for the GBR have been the subject of "vicious" debates within the scientific community. In an ongoing feud, Larcombe and Ridd (2018) argue that systemic failings occur in the quality control of environmental science, especially in "agenda-driven science" used to inform government policy. They cited the science related to eutrophication of the GBR as a case in point, concluding that it overstates declines in ecosystem conditions and the need for the prescribed management actions. Leading scientists involved in Reef Plan assessments offered point-by-point rebuttals, bluntly arguing: "that the critiques 
demonstrate biases, misinterpretation, selective use of data and oversimplification, and also ignore previous responses to their already published claims" (Schaffelke et al., 2018).

\section{BARRIERS AND BRIDGES}

Based on experiences drawn from the globally distributed campaigns I have categorized the barriers to abating coastal eutrophication under five overarching themes (Table 1). I briefly summarize these particular barriers and consider bridges that can help overcome them.

\section{Advancing Actionable Science}

Limited knowledge of the causes and consequences of changes observed in coastal ecosystems during the 20th century initially slowed action to abate eutrophication, even in those regions where there are now substantial campaigns to accomplish this objective. Are the symptoms just natural phenomena? Do they actually matter to the health of the ecosystem and living resources on which humans depend? Are they stimulated by organic matter or nutrients, and which nutrients? What are the principal nutrient sources and can they be reduced? What level of rehabilitation can be achieved? We now have a wealth of understanding that can assist other regions of the world abate eutrophication more expeditiously. The global scientific community can assist by applying their knowledge and experience to accelerate diagnosis and prognosis.

Even in regions that are comparatively well studied, understanding is often fragmentary across the biophysical and social sciences and among agricultural, hydrological and marine sciences. Fragmentation results not only from the cultural segregation among fields of science and engineering, but also because of the narrow focus of research sponsors. In the Chesapeake Bay region the states have sustained the infrastructure of research institutions and the salaries of core scientists, but these scientists have to compete for research support at a national level, where priorities are not well aligned with the requirements of Chesapeake Bay rehabilitation. Scientists and agency analysts are then left to weld together the fragments of understanding. To bridge not only disciplinary barriers but also international ones, research funding agencies in the EU countries bordering the Baltic Sea pooled their resources and attracted additional support from the European Commission to sponsor the strategic research program BONUS: Science for a Better Future of the Baltic Sea Region. The program has been very successful in advancing actionable research and building transdisciplinary and international science (Snoeijs-Leijonmalm et al., 2017). Its expansion to include the North Sea, with additional national funding partners, is under active development.

Often-public controversies among scientists regarding causes and solutions have sometimes hindered or confused purposeful and efficient abatement of coastal eutrophication. Examples were provided from Baltic and Black seas, Gulf of Mexico, Chesapeake Bay and Australia. Often, critics were oceanographers, limnologists, agricultural scientists or economists unfamiliar with the science underpinning efforts to abate coastal eutrophication or without a broader perspective on how the planetary boundaries for biogeochemical flows of nitrogen and phosphorus have been breached (Steffen et al., 2015). Armed with such a global perspective, it would be surprising if extensive hypoxia had not developed in the northern Gulf of Mexico as nitrate loading from the Mississippi River tripled. In some cases, controversies were driven by feelings of disciplinary exclusion and even personal animus. Traditional institutional mechanisms such as advisory boards and review committees are too often inconclusive in resolving such controversies, falling in the trap of focusing on the unknowns rather than what is known with some confidence. More effective bridging of this barrier requires more responsive and conclusive adjudication of key issues and controversies.

\section{Providing Accountable Governance}

Governance of campaigns to abate eutrophication are commonly handicapped by the lack of authority and responsibility by the guiding intergovernmental council. Contrast, for example, the Mississippi River/Gulf of Mexico Watershed Nutrient Task Force, which has resisted even allocating voluntary nutrient load reduction targets, with the HELCOM Heads of Delegation or the Chesapeake Bay Program Governing Council. The former are mid-level officials, some of whom regard their role as preventing aggressive abatement actions, as opposed to officers who are elected or otherwise directly accountable to the public for delivering on commitments. Engagement of responsible parties at the highest practicable level is an important bridge to achieving reliable, and even binding, commitments and account for outcomes.

Public awareness and support is essential for the success of campaigns to abate eutrophication because such campaigns require sustained efforts and incur costs to the public treasury, ratepayers or responsible parties vested in the status quo. Where the source of the nutrient loads is remote from the coastal waters experiencing the effects of eutrophication, e.g., in the Corn Belt from the Gulf of Mexico, the Danube Basin to the Black Sea, and the farms of Pennsylvania for the Chesapeake Bay, this can be problematic. The affected fishers along the coast are usually not organized around the issue of eutrophication and have muted voices compared to agriculture, for example. Non-governmental organizations can be highly effective in advocating for environmental protection and rehabilitation as demonstrated in the Baltic Sea and Chesapeake Bay regions. The news media can also sustain public awareness, but many are now financially challenged to retain experienced environmental journalists. However, new opportunities are provided via online news and social media. Scientists enjoy a trusted position in society and can be effective in communicating understanding concerning the causes and risks of eutrophication and the benefits of its abatement by honing skills in working through NGOs and the news media.

Over-generalized commitments, such as reducing the extent of hypoxia in the northern Gulf of Mexico or avoiding exceeding nutrient loads to the Black Sea, are unlikely to yield intended results. At a minimum, the nutrient load reductions needed to achieve good environmental status (EU) or a TMDL (US) must be estimated and then proportionally allocated to the 
responsible jurisdictions and sectors. Even though politically determined allocations may not be the most hydrogeochemically or economically efficient (Iho et al., 2015), they provide the framework for actions and accountability.

Even then, voluntary, non-binding commitments to reduce nutrient loads have proven ineffective in achieving abatement targets. Technological improvements in wastewater treatment required by directives or regulations resulted in substantial load reductions in the Baltic and North seas, the North-East Atlantic, and Tampa and Chesapeake Bay. However, general frameworks such as the Water Framework Directive or TMDL have been less successful in achieving load reductions needed from diffuse sources (Voulvoulis et al., 2017). This is particularly true for agriculture, which in the U. S. is exempt from regulation under the Clean Water Act and in Europe is weakly and inconsistently regulated under Nitrates Directive. In June 2018, the EU Court of Justice ruled that Germany had breached the Nitrate Directive by allowing an excessive use of manure as fertilizer. A bridge to more effective reduction of diffuse agricultural nutrient losses is exemplified by the Danish action plans, progressively implemented since 1985, which included obligatory limitations on fertilizer application and requirements for manure management and planting of catch crops (Hansen et al., 2017). These were eventually rolled back in 2016 because of political pressures.

\section{Reducing Nutrient Loads}

Narrow debates over whether reducing loads of nitrogen or loads of phosphorous was required to abate coastal eutrophication confounded most of the campaigns at one time or another. These remained unresolved not only because of dogmatic claims that only one nutrient can be limiting, but also on overly simplistic interpretations of $\mathrm{N}: \mathrm{P}$ concentrations compared to the Redfield ratio or bioassays performed in immediate receiving waters. The case studies reveal the complexity of nutrient limitation, as either nutrient can be limiting seasonally or with distance from the source. Within the open Baltic Sea reducing the availability of phosphorus is essential to breaking the vicious circle of hypoxia and diazotrphic nitrogen fixation (Vahtera et al., 2007; Savchuk, 2018), while reduction of nitrogen loads is also required to reverse eutrophication in coastal regions. Reducing phosphorus loads to waters with highly enriched concentrations of nitrogen risks exporting unassimilated nitrogen farther afield or changing the nutrient balance in ways that promote harmful algal blooms (Paerl et al., 2018). The bridge across this barrier is a strategy of dual-nutrient control that takes into account the specific conditions and processes along full environmental transitions and appropriately phases nitrogen and phosphorus load reductions (Conley et al., 2009; Paerl et al., 2016).

The atmospheric deposition of nitrogen emanating from emissions of nitrogen oxides from fossil fuel combustion or from releases of ammonia from animal wastes is often not taken into account in eutrophication abatement strategies. Whether falling on forested or agricultural landscapes, urban surfaces or directly onto coastal waters, the atmosphere can be a significant source of nitrogen inputs, but one that is regarded beyond control of water pollution agencies. Significant reductions in atmospheric deposition of nitrogen within the Chesapeake Bay catchment and North Sea were realized through regulations developed under the air quality directives and laws designed primarily to reduce human health risks. This has had less effect on the open Baltic Sea, where nitrogen fixation has compensated for reduced atmospheric deposition. Nonetheless, projections of future reductions in deposition are now included in the sustainable implementation plans for nitrogen loads to the Chesapeake and Tampa bays and even greater gains are possible as we rely more on renewable energy.

Once required by directive, national law or regulation, the collection and advanced treatment of wastewaters resulted in substantial reductions in loadings of phosphorus, and then nitrogen, leading to significant abatement of eutrophication. Except for Denmark, reductions in diffuse sources of nutrient loads, primarily from agriculture, have generally failed to achieve load reduction goals, even taking into account lags between implementation of practices and water quality outcomes. For economic and social reasons, policy makers have been reluctant to impose regulatory requirements on agriculture. Rather than following a "polluter pays" principle, policies have often taken a "pay the polluter" approach in the form of subsidies and technical assistance for implementation of pollution reduction practices (Iho et al., 2015). This has produced only modest nutrient load reductions, particularly when contravened by other agricultural policies, including commodity subsidies that incentivize high yield and biofuel mandates.

Bridges to overcome barriers to more effective abatement of diffuse agricultural sources differ between phosphorus and nitrogen because of their origins and hydrogeochemical behaviors. For nitrogen, strategies should be fundamentally be founded on minimizing the nitrogen surplus (the difference between the nitrogen applied and the nitrogen removed in crops), a concept also captured in achieving a nitrogen balance (McLellan et al., 2018) or maximizing nitrogen use efficiency (Zhang X. et al., 2015). Many studies (e.g., Osmond et al., 2015) have demonstrated that farmers commonly exceed agronomic prescriptions of application rates, which already err on the side of achieving maximum yields. The nitrogen surplus is a robust determinant of nitrogen losses and can be calculated from readily available farm data. Additional components to the strategy should include targeting of mitigation measures to portions of catchments that, because of soil and other factors, disproportionately contribute to nutrient loads (e.g., Hashemi et al., 2018), controlling sub-surface drainage systems to promote nitrogen assimilation in crops and denitrification in soils (Poole et al., 2018), and construction of wetlands that receive farm runoff (Tournebize et al., 2017). Ribaudo et al. (2016) estimated that if it were required that nitrogen applications not exceed the agronomic needs of crops in order to be eligible for US federal conservation and commodity program payments (including crop insurance), excess nitrogen application in the MississippiAtchafalaya River Basin could be reduced by $60 \%$. Such compliance requirements are already used for soil conservation and wetland protection. If strict regulation of agricultural practices is achievable, such compliance requirements could be extended to constraining the nitrogen surplus and additional pollution-reduction practices in targeted areas. 
At the same time that efforts are underway to stem the loss of nutrients from agricultural food production, producing crops for biofuels has grown rapidly, displacing food crops, intensifying the cultivation of maize, and expanding cultivation of marginal lands. Planned expansion in production of maize-based ethanol would increase the flux of dissolved inorganic nitrogen down the Mississippi-Atchafalaya River system sufficient to offset the $22 \%$ interim reduction goal of the Hypoxia Action Plan (Donner and Kucharik, 2008). Bridges over this barrier to eutrophication abatement include requiring more stringent interventions to control nutrient pollution for fuel-production agriculture and accelerating the transition to cellulose rather than starch-based biofuels. Perennial grasses grown for biofuels require much less fertilization, sequester carbon, and have dramatically less nitrate leaching and nitrous oxide production (Smith et al., 2013; Robertson et al., 2017; Ha et al., 2018).

Campaigns to abate eutrophication should be neither oblivious nor resigned to the long lag times between actions to reduce nitrogen and phosphorus losses and reductions in delivered loads. Accounting for progress through models that assume reductions in delivered loads are immediate, such as in the CBP, belies the reality that it may take years for these reductions to be fully realized. It is critical to ascertain the influence of lag times in the catchment through more diagnostic groundwater monitoring and modeling (e.g., Hansen et al., 2017), not only to avoid imposing changes to intervention measures due to impatience (Vero et al., 2018), but also to guide when and how to make adjustments if they are not effective. Progress can be accelerated by addressing rapid transport pathways, such as surface runoff of phosphorus and the large soil phosphorus reserves in croplands (McCrackin et al., 2018) and large nitrogen losses from subsurface drainage systems. About half of the agricultural nitrate load in the Mississippi River catchment comes from such tile drainage systems (McCrackin et al., 2017) and can be substantially reduced by use of controlled drainage, especially if the drainage then flows through wood-chip bioreactors or constructed wetlands (Christianson et al., 2018). Rehabilitation of existing wetlands and riparian zones is another fast-acting measure for reducing nutrient loads.

\section{Assessing Outcomes and Adapting Strategies}

Assessing outcomes requires monitoring of changing inputs and ecosystem responses, but monitoring is often inadequate for this task (e.g., hypoxia monitoring in the Gulf of Mexico). Even where there is adequate monitoring it may be not be sustained (e.g., the exemplary Danish monitoring program) or monitoring data produced are not regularly interpreted (e.g., until recently in the $\mathrm{CBP}$ ). Bridging the monitoring barrier requires a truly sustained commitment to monitoring of nutrient inputs and essential indicators and processes of coastal ecosystem responses. Periodic integrated assessments of outcomes based on monitoring results (Andersen et al., 2015; Zhang et al., 2018) should be institutionalized.

Models are also required to connect nutrient sources, delivery mechanisms, fate and responses (Ménesguen and Lacroix, 2018). They should only be as complex as necessary. Even in this era of high-speed computing, overly complex and highly resolved models may convey a sense of false precision and constrain their use to explore abatement options. Use and intercomparison of multiple models, with various levels of complexity and agility, and the reporting of confidence limits rather than single deterministic projections, should be encouraged.

Over-reliance on models not reconciled with observations is dangerous. While useful for tracking abatement actions, use of model estimates of load reductions, as the CBP, risks false confidence in the degree of implementation and effectiveness of these actions and belies the reality of lagged responses. Truly adaptive management approaches offer a bridge over this pitfall. Adaptive management (Allen and Garmestani, 2015) requires reconciling model estimates, including pertinent lags, with observed outcomes on a regular basis and a management commitment to make adjustments to strategies based on these assessments.

Because of compounding pressures that accompanied the eutrophication of a coastal ecosystem, abatement of nutrient loading to the targeted level might not achieve the intended rehabilitation of the ecosystem. Intervention within the coastal system may be an option, including enhancing denitrification in wetlands, seagrass beds and restored oyster reefs; enhancing sediment sequestration; hydrological engineering to increase flushing and nutrient export from relatively enclosed water bodies; and seaweed or shellfish aquaculture (Duarte and KrauseJensen, 2018). Of course, precaution should be used to avoid unintended or undesirable consequences.

\section{Addressing Climate Change}

Campaigns to abate coastal eutrophication are now taking place at the same time that ecosystems are being altered by global climate change. The discharges and nutrient loads from rivers will be affected by increased temperature and changes in the amount and distribution of precipitation. For example, Sinha et al. (2017) estimated that precipitation changes-both total and extreme precipitation-could increase riverine total nitrogen loading from the continental US by $19 \%$ (median estimate) by the end of the century. In addition, coastal waters are influenced by increased temperature, sea-level rise and changes in cloudiness and winds in ways that affect the formation of hypoxia and other effects of eutrophication. Models project that these various forces will exacerbate hypoxia in the Baltic Sea (Saraiva et al., 2018), northern Gulf of Mexico (Laurent et al., 2018) and Chesapeake Bay (Irby et al., 2018), counteracting improvements made by reducing nutrient loading and requiring more aggressive load reductions to achieve rehabilitation goals. The CBP is currently estimating how this will affect the Total Maximum Daily Load for nitrogen and phosphorus even within 2025 time frame for achievement. Scientific analysts will have to continually reassess future conditions that are achievable and the climate-smart strategies capable of reaching evolving goals.

The higher greenhouse gas concentrations rise, the more difficult it will be to abate coastal eutrophication and the accompanying complications from acidification. Yet, waterquality and climate change strategies are almost always decoupled. Analysts run models using high emissions pathways, 
counseling managers to plan for the worst. Yet, if human society were to meet the goals of the Paris Climate Agreement, global temperature would be stabilized below a $2^{\circ} \mathrm{C}$ increase. As nations work to reduce emissions, there will be many opportunities to reduce nutrient losses to the sea also, including the near-elimination of atmospheric deposition of nitrogen, carbon sequestration, and adjustments of agricultural practices responsible for large greenhouse gas emissions. The development of mitigation and adaptation strategies that limit climate change and its impacts is the super-bridge that must be built during the mid-21st century. Done smartly, it could present significant co-benefits for abating coastal eutrophication.

\section{CONCLUSION}

While often more challenging than anticipated, campaigns to abate 20th century eutrophication of coastal ecosystems have achieved rehabilitation targets or are on pathways toward

\section{REFERENCES}

Abal, E. G., Dennison, W. C., and Greenfield, P. F. (2001). Managing the Brisbane River and Moreton Bay: an integrated research/management program to reduce impacts on an Australian estuary. Water Sci. Technol. 43, 57-90. doi: 10.2166/ wst. 2001.0508

Albert, S., O’Neil, J. M., Udy, J. W., Ahern, K. S., O’Sullivan, C. M., and Dennison, W. C. (2005). Blooms of the cyanobacterium Lyngbya majuscula in coastal Queensland, Australia: disparate sites, common factors. Mar. Pollut. Bull. 51, 428-437. doi: 10.1016/j.marpolbul.2004.10.016

Allen, C., and Garmestani, A. (eds). (2015). Adaptive Management of SocialEcological Systems. Dordrecht: Springer. doi: 10.1007/978-94-017-9682-8

Amin, M. N., Kroeze, C., and Stokal, M. (2017). Human waste: an underestimated source of nutrient pollution in coastal seas of Bangladesh, India and Pakistan. Mar. Pollut. Bull. 118, 131-140. doi: 10.1016/j.marpolbul.2017.02.045

Andersen, J. H., Carstensen, J., Conley, D. J., Dromph, K., Fleming-Lehtinen, V., Guftasson, G. G., et al. (2015). Long-term temporal and spatial trends in eutrophication status of the Baltic Sea. Biol. Rev. 92, 135-149. doi: 10.1111/brv. 12221

Artioli, Y., Friedrich, J., Gilbert, A. J., McQuatters-Gollow, A., Mee, L. D., Vermaat, J. E., et al. (2008). Nutrient budgets for European seas: a measure of the effectiveness of nutrient reduction policies. Mar. Pollut. Bull. 56, 1609-1617. doi: 10.1016/j.marpolbul.2008.05.027

Bianchi, T. S., Allison, M. A., Chapman, P., Cowan, J. H., Dagg, M. J., Day, J. W., et al. (2010). New approaches to the Gulf hypoxia problem. Eos Trans. Am. Geophys. Union 91:173. doi: 10.1029/2010EO190006

Bianchi, T. S., DiMarco, S. F., Allison, M. A., Chapman, P., Cowan, J. H., Hetland, R. H., et al. (2008). Controlling hypoxia on the U.S. Louisiana shelf: beyond the nutrient-centric view. Eos Trans. Am. Geophys. Union 89, 236-237. doi: 10.1029/2008EO260005

Boesch, D. F. (2003). Continental shelf hypoxia: some compelling answers. Gulf Mex. Sci. 21, 143-145. doi: 10.18785/goms.2102.06

Boesch, D. F., Boynton, W. R., Crowder, L. B., Diaz, R. J., Howarth, R. W., Mee, L., et al. (2009). Nutrient enrichment drives Gulf of Mexico hypoxia. Eos Trans. Am. Geophys. Union 90, 117-118. doi: 10.1029/2009EO140001

Boesch, D. F., Brinsfield, R. B., and Magnien, R. E. (2001). Chesapeake Bay eutrophication: scientific understanding, ecosystem restoration, and challenges for agriculture. J. Environ. Qual. 30, 303-320. doi: 10.2134/jeq2001.302303x

Bourgault, D., and Cyr, F. (2015). Hypoxia in the St. Lawrence estuary: how a coding error led to the belief that "physics controls spatial patterns." PLoS One 10:e0138858. doi: 10.1371/journal.pone.0138858

Bricker, S. B., Longstaff, B., Dennison, W., Jones, A., Boicourt, K., Wicks, C., et al. (2008). Effects of nutrient enrichment in the nation's estuaries: those targets. This collective experience reveals many common barriers to rehabilitation and bridges to overcome them for science, governance, achievement of nutrient load reductions, assessing outcomes and adapting strategies, and addressing the complications of 21 st century climate change.

\section{AUTHOR CONTRIBUTIONS}

DB conceived, researched, and wrote the paper.

\section{FUNDING}

This work was supported by the University of Maryland Center for Environmental Science and the Keith Campbell Foundation for the Environment, which also provided open access publication fees.

a decade of change. Harmful Algae 8, 21-32. doi: 10.1016/j.hal.2008. 08.028

Capet, A., Beckers, J.-M., and Grégoire, M. (2013). Drivers, mechanisms and longterm variability of seasonal hypoxia on the Black Sea northwestern shelf is there any recovery after eutrophication? Biogeosciences 10, 3943-3962. doi: $10.5194 / \mathrm{bg}-10-3943-2013$

Carstensen, J., Sánchez-Camacho, M., Duarte, C. M., Krause-Jensen, D., and Marbà, N. (2011). Connecting the dots: responses of coastal ecosystems to changing nutrient concentrations. Environ. Sci. Technol. 45, 9122-9132. doi: $10.1021 / \mathrm{es} 202351 \mathrm{y}$

Chen, J., Pan, D., Liu, M., Mao, Z., Zhu, Q., Chen, N., et al. (2017). Relationships between long-term trend of satellite-derived chlorophyll-a and hypoxia off the Changjiang Estuary. Estuaries Coast. 40, 1055-1065. doi: 10.1007/s12237-0160203-0

Choi, Y. D. (2007). Restoration ecology to the future: a call for new paradigm. Restor. Ecol. 15, 351-353. doi: 10.1111/j.1526-100X.2007.00224.x

Christianson, R., Christianson, L., Wong, C., Helmers, M., McIsaac, G., Mulla, D., et al. (2018). Beyond nutrient strategies: common ground to accelerate agricultural water quality improvements in the upper Midwest. J. Environ. Manage. 206, 1072-1080. doi: 10.1016/j.jenvman.2017.11.051

Claussen, U., Zevenboom, W., Brockmann, U., Topcu, D., and Bot, P. (2009). Assessment of the eutrophication status of transitional, coastal and marine waters within OSPAR. Hydrobiologia 629, 49-58. doi: 10.1007/s10750-0099763-3

Conley, D. J. (2012). Saving the Baltic Sea. Nature 486, 463-464. doi: 10.1038/ 486463a

Conley, D. J., Carstensen, J., Aigars, J., Axe, P., Bonsdorff, E., Eremina, T., et al. (2011). Hypoxia is increasing in the coastal zone of the Baltic Sea. Environ. Sci. Technol. 45, 6777-6783. doi: 10.1021/es201212r

Conley, D. J., Paerl, H. W., Howarth, R. W., Boesch, D. F., Seitzinger, S. P., Havens, K. E., et al. (2009). Controlling eutrophication: nitrogen and phosphorus. Science 323, 1014-1015. doi: 10.1126/science.1167755

Costanza, R., and Greer, J. (1995). "The Chesapeake Bay and its watershed: a model for sustainable ecosystem management?," in Barriers and Bridges to the Renewal of Ecosystems and Institutions, eds L. H. Gunderson, C. S. Holling, and S. S. Light (New York, NY: Columbia University Press), 171-213.

Das, A., Justic, D., Swenson, E., Turner, R. E., Inoue, M., and Park, D. (2011). Coastal land loss and hypoxia: the 'Outwelling' hypothesis revisited. Environ. Res. Lett. 6:025001. doi: 10.1088/1748-9326/6/2/025001

Davis, J. R., and Koop, K. (2006). Eutrophication in Australian rivers, reservoirs and estuaries-a southern hemisphere perspective on the science and its implications. Hydrobiologia 559, 23-76. doi: 10.1007/s10750-005$4429-2$ 
de Jong, F. (2006). Marine Eutrophication in Perspective: On the Relevance of Ecology for Environmental Policy. Berlin: Springer, 335. doi: 10.1007/3-54033648-6

Degobbis, D., Precali, R., Ferrari, C. R., Djakovac, T., Rinaldi, A., Ivančić, I., et al. (2005). Changes in nutrient concentrations and ratios during mucilage events in the period 1999-2002. Sci. Total Environ. 353, 103-114. doi: 10.1016/j.scitotenv. 2005.09.010

Desmit, X., Thieu, V., Billen, G., Campuzano, F., Dulière, V., Garnier, J., et al. (2018). Reducing eutrophication may require a paradigmatic change. Sci. Total Environ. 635, 1444-1466. doi: 10.1016/j.scitotenv.2018.04.181

Donner, S. D., and Kucharik, C. J. (2008). Corn-based ethanol production compromises goal of reducing nitrogen export by the Mississippi River. Proc. Natl. Acad. Sci. U.S.A. 105, 4513-4518. doi: 10.1073/pnas.070830 0105

Duarte, C. M., Conley, D. J., Carstensen, J., and Sánchez-Camacho, M. S. (2009). Return to Neverland: shifting baselines affect eutrophication restoration targets. Estuaries Coast. 32, 29-36. doi: 10.1007/s12237-008-9111-2

Duarte, C. M., and Krause-Jensen, D. (2018). Intervention options to accelerate ecosystem recovery from coastal eutrophication. Front. Mar. Sci. 5:470. doi: 10.3389/fmars.2018.00470

Elofsson, K., and von Brömssen, C. (2017). The revealed preferences of Baltic Sea governments: goals, policy instruments, and implementation of nutrient abatement measures. Mar. Pollut. Bull. 118, 188-196. doi: 10.1016/j.marpolbul. 2017.02.014

Emeis, K.-C., van Beusekom, J., Callies, U., Ebinghaus, R., Kannen, A., Kraus, G., et al. (2015). The North Sea - A shelf sea in the Anthropocene. J. Mar. Syst. 141, 18-33. doi: 10.1016/j.jmarsys.2014.03.012

EPA Science Advisory Board (2008). Hypoxia in the Northern Gulf of Mexico: An Update by the EPA Science Advisory Board. Washington, DC: Environmental Protection Agency.

Eshleman, K. N., and Sabo, R. D. (2016). Declining nitrate-N yields in the Upper Potomac River Basin: what is really driving progress under the Chesapeake Bay restoration? Atmos. Environ. 146, 280-289. doi: 10.1016/j.atmosenv.2016. 07.004

Fennel, K., Laurent, A., Hetland, R., Justić, D., Ko, D. S., Lehrter, J., et al. (2016). Effects of model physics on hypoxia simulations for the northern Gulf of Mexico: a model intercomparison. J. Geophys. Res. Oceans 121, 5731-5750. doi: 10.1002/2015JC011577

Ferber, D. (2004). Dead zone fix not a dead issue. Science 305:1557. doi: 10.1126/ science.305.5690.1557

Gibbes, B., Grinham, A., Neil, D., Olds, A., Maxwell, P., Connolly, R., et al. (2014). "Moreton Bay and its estuaries: a sub-tropical system under pressure from rapid population growth," in Estuaries of Australia in 2050 and Beyond, ed. E. Wolanski (Dordrecht: Springer), 203-222.

Glibert, P. M., Heil, C. A., O’Neil, J. M., Dennison, W. C., and O’Donohue, M. J. H. (2006). Nitrogen, phosphorus, silica and carbon in Moreton Bay, Queensland, Australia: differential limitation of phytoplankton biomass and production. Estuaries Coast. 29, 209-221. doi: 10.1007/BF02781990

Greening, H., Janicki, A., Sherwood, E. T., Pribble, R., and Johansson, J. O. R. (2014). Ecosystem responses to long-term nutrient management in an urban estuary: Tampa Bay, Florida, USA. Estuar. Coast. Shelf Sci. 151, A1-A16. doi: 10.1016/j.ecss.2014.10.003

Gunderson, L. H., Hollings, C. S., and Light, S. S. (1995). Barriers and Bridges to the Renewal of Ecosystems and Institutions. New York, NY: Columbia University Press, 593.

Gurbisz, C., and Kemp, W. M. (2014). Unexpected resurgence of a large submersed plant bed in Chesapeake Bay: analysis of time series data. Limnol. Oceanogr. 59, 482-494. doi: 10.4319/lo.2014.59.2.0482

Ha, M., Xhang, Z., and Wu, M. (2018). Biomass production in the Lower Mississippi River Basin: mitigating associated nutrient and sediment discharge to the Gulf of Mexico. Sci. Total Environ. 635, 1585-1599. doi: 10.1016/j. scitotenv.2018.01.184

Hansen, B., Thorling, L., Schullehner, J., Termansen, M., and Dalgaard, T. (2017). Groundwater nitrate response to sustainable nitrogen management. Sci. Rep. 7:8566. doi: 10.1038/s41598-017-07147-2

Hashemi, F., Olesen, J. E., Jabloun, M., and Hansen, A. L. (2018). Reducing uncertainty of estimated nitrogen load reductions to aquatic systems through spatially targeting agricultural mitigation measures using groundwater nitrogen reduction. J. Environ. Manage. 218, 451-464. doi: 10.1016/j.jenvman.2018.04. 078

Heil, C. A., Dixon, L. K., Hall, E., Garrett, M., Lenes, J. M., O’Neil, J. M., et al. (2014). Blooms of Karenia brevis (Davis) G. Hansen \& Ø. Moestrup on the West Florida Shelf: nutrient sources and potential management strategies based on a multi-year regional study. Harmful Algae 38, 127-140. doi: 10.1016/j.hal.2014. 07.016

Hughes, T. P., Kerry, J. T., Baird, A. H., Connolly, S. R., Dietzel, A., Eakin, C. M., et al. (2018). Global warming transforms coral reef assemblages. Nature 554, 492-496. doi: 10.1038/s41586-018-0041-2

Iho, A., Ribaudo, M., and Hyytiäinen, K. (2015). Water protection in the Baltic Sea and the Chesapeake Bay: institutions, policies and efficiency. Mar. Pollut. Bull. 93, 81-93. doi: 10.1016/j.marpolbul.2015.02.011

Irby, I. D., Friedrichs, M. A. M., Da, F., and Hinson, K. E. (2018). The competing impacts of climate change and nutrient reductions on dissolved oxygen in Chesapeake Bay. Biogeosciences 15, 2649-2668. doi: 10.5194/bg-15-2649-2018

Jansson, B.-O., and Velner, H. (1995). “The Baltic: the sea of surprises," in Barriers and Bridges to the Renewal of Ecosystems and Institutions, eds L. H. Gunderson, C. S. Holling, and S. S. Light (New York, NY: Columbia University Press), 292-372.

Jiang, Q., He, J., Wu, J., Hu, X., Ye, G., and Christakos, G. (2018). Assessing the severe eutrophication status and spatial trend in the coastal waters of Zhejiang Province (China). Limnol. Oceanogr. 64, 3-17. doi: 10.1002/lno.11013

Jokinen, S. A., Virtasalo, J. J., Jilbert, T., Kaiser, J., Dellwig, O., Arz, H. W., et al. (2018). A 1500-year multiproxy record of coastal hypoxia to the northern Baltic Sea indicates unprecedented deoxygenation over the 20th century. Biogeosciences 15, 3975-4001. doi: 10.5194/bg-15-3975-2018

Jones, C. S., Nielsen, J. K., Schilling, K. E., and Weber, L. J. (2018). Iowa stream nitrate and the Gulf of Mexico. PLoS One 213:e0195930. doi: 10.1371/journal. pone.0195930

Karydis, M., and Kitsiou, D. (2012). Eutrophication and environmental policy in the Mediterranean Sea: a review. Environ. Monit. Assess. 184, 4931-4984. doi: 10.1007/s10661-011-2313-2

Kemp, W. M., Boynton, W. R., Adolf, J. E., Boesch, D. F., Boicourt, W. C., Brush, G. et al. (2005). Eutrophication of Chesapeake Bay: historical trends and ecological interactions. Mar. Ecol. Prog. Ser. 303, 1-29. doi: 10.3354/meps303001

Kleinman, P. J. A., Sharpley, A. N., McDowell, R. W., Flaten, D. N., Buda, A. R., Tao, L., et al. (2011). Managing agricultural phosphorus for water quality protection: principles for progress. Plant Soil 349, 169-182. doi: 10.1007/ s11104-011-0832-9

Kramer, B. J., Davis, T. W., Meyer, K. A., Rosen, B. H., Goleski, J. A., Dick, G. J., et al. (2018). Nitrogen limitation, toxin synthesis potential, and toxicity of cyanobacterial populations in Lake Okeechobee and the St. Lucie River Estuary, Florida, during the 2016 state of emergency event. PLoS One 13:e0196278. doi: 10.1371/journal.pone.0196278

Kronvang, B., Andersen, H. E., Børgesen, C., Dalgaad, T., Larsen, S. E., Bøgestrand, J., et al. (2008). Effects of policy measures implemented in Denmark on nitrogen pollution of the aquatic environment. Environ. Sci. Policy 11, 144-152. doi: 10.1016/j.envsci.2007.10.007

Kroon, F. J., Thorburn, P., Schaffelke, B., and Whitten, S. (2016). Towards protecting the Great Barrier Reef from land-based pollution. Glob. Change Biol. 22, 1985-2002. doi: 10.1111/gcb.13262

Kubo, A., Hashihama, F., Kanda, J., Horimoto-Miyazaki, N., and Ishimaru, T. (2019). Long-term variability of nutrient and dissolved organic matter concentrations in Tokyo Bay beween 1989 and 2015. Limnol. Oceanogr. 64, S209-S222. doi: 10.1002/lno.10796

Larcombe, P., and Ridd, P. (2018). The need for a formalized system of quality control for environmental policy-science. Mar. Pollut. Bull. 126, 449-461. doi: 10.1016/j.marpolbul.2017.11.038

Larsson, M. E., Ajani, P. A., Rubio, A. M., Guise, K., McPherson, R. G., Brett, S. J., et al. (2017). Long-term perspective on the relationship between phytoplankton and nutrient concentrations in a southeastern Australian estuary. Mar. Pollut. Bull. 114, 227-238. doi: 10.1016/j.marpolbul.2016.09.011

Laurent, A., Fennel, K., Ko, D. S., and Lehrter, J. (2018). Climate change projected to exacerbate impacts of coastal eutrophication in the northern Gulf of Mexico. J. Geophys. Res. Oceans 123, 3408-3426. doi: 10.1002/2017JC013583

Lee, C.-K., Park, T.-G., Park, Y.-T., and Lim, W.-A. (2013). Monitoring and trends in harmful algal blooms and red tides in Korean coastal waters, with emphasis 
on Cochlodinium polykrikoides. Harmful Algae 30, S3-S14. doi: 10.1016/j.hal. 2013.10.002

Lee, J., Park, K.-T., Lim, J.-H., Yoon, J.-E., and Kim, I.-N. (2018). Hypoxia in Korean coastal waters: a case study of the natural Jinhae Bay and artificial Shihwa Bay. Front. Mar. Sci. 5:70. doi: 10.3389/fmars.2018.00070

Lee, J. H. W., Harrison, P. J., Kuang, C., and Yin, K. (2006). "Eutrophication dynamics in Hong Kong coastal waters: physical and biological interactions," in The Environment in Asia Pacific Harbours, ed. E. Wolanski (London: Springer), 187-206.

Lefcheck, J. S., Orth, R. J., Dennison, W. C., Wilcox, D. J., Murphy, R. R., Keisman, J., et al. (2018). Long-term nutrient redutions lead to the unprecedented recovery of a temperate coastal region. Proc. Natl. Acad. Sci. U.S.A. 115, 3658-3662. doi: 10.1073/pnas. 1715798115

Lefort, S., Gratton, Y., Mucci, A., Dadou, I., and Gilbert, D. (2012). Hypoxia in the Lower St. Lawrence Estuary: how physics controls spatial patterns. J. Geophys. Res. 117:C07018. doi: 10.1029/2011JC007751

Linker, L. C., Batiuk, R. A., Shenk, G. W., and Cerco, C. F. (2013). Development of the Chesapeake Bay watershed Total Maximum Daily Load allocation. J. Am. Water Resour. Assoc. 49, 986-1006. doi: 10.1111/jawr.12105

Liu, D., Keesing, J. K., He, P., Wang, Z., Shi, Y., and Wang, Y. (2013). The world's largest macroalgal bloom in the Yellow Sea, China: formation and implications. Estuar. Coast. Shelf Sci. 129, 2-10. doi: 10.1016/j.ecss.2013.05.021

Lubell, M. (2004). Resolving conflict and building cooperation in the National Estuary Program. Environ. Manage. 33, 677-691. doi: 10.1007/s00267-0030066-6

Macias, D., Garcia-Gorriz, E., and Stips, A. (2017). Major fertilization sources and mechanisms for Mediterranean Sea coastal ecosystems. Limnol. Oceanogr. 63, 897-914. doi: 10.1002/lno.10677

McCrackin, M. L., Cooter, E. J., Dennis, R. L., Harrison, J. A., and Compton, J. E. (2017). Alternative futures of dissolved inorganic nitrogen export from the Mississippi River Basin: influence of crop management, atmospheric deposition, and population growth. Biogeochemistry 133, 263-277. doi: 10.1007/ s10533-017-0331-z

McCrackin, M. L., Muller-Karulis, B., Gustafsson, B. G., Howarth, R. W., Humborg, C., Svanbäck, A., et al. (2018). A century of legacy phosphorus dynamics in a large drainage basin. Glob. Biogeochem. Cycles 32, 1107-1122. doi: 10.1029/2018GB005914

McIsaac, G. F., David, M. B., and Gertner, G. Z. (2016). Illinois River nitratenitrogen concentrations and loads: long-term variation and association with watershed nitrogen inputs. J. Environ. Qual. 45, 1268-1275. doi: 10.2134/ jeq2015.10.0531

McLellan, E. L., Cassman, K. G., Eagle, A. J., Woodbury, P. B., Sela, S., Tonitto, C., et al. (2018). The nitrogen balancing act: tracking the environmental performance of food production. Bioscience 68, 194-203. doi: 10.1093/biosci/ bix164

Mee, L. (2006). Reviving dead zones. Sci. Am. 295, 79-85. doi: 10.1038/ scientificamerican1106-78

Mee, L. D., Friedrich, J., and Gomoiu, M. T. (2005). Restoring the Black Sea in times of uncertainty. Oceanography 18, 100-111. doi: 10.5670/oceanog.2005.45

Ménesguen, A., Desmit, Z., Dulière, V., Lacroix, G., Thouvenin, B., Thieu, V., et al. (2018). How to avoid eutrophication in coastal seas? A new approach to derive river-specific combined nitrate and phosphate maximum concentrations. Sci. Total Environ. 628-629, 400-414. doi: 10.1016/j.scitotenv.2018.02.025

Ménesguen, A., and Lacroix, G. (2018). Modelling the marine eutrophication: a review. Sci. Total Environ. 638, 339-354. doi: 10.1016/j.scitotenv.2018.04.183

Moksnes, P. O., Eriander, L., Infantes, E., and Holmer, M. (2018). Local regime shifts prevent natural recovery and restoration of lost eelgrass beds along the Swedish west coast. Estuaries Coast. 41, 1712-1731. doi: 10.1007/s12237-0180382-y

Murphy, J. C., Hirsch, R. M., and Sprague, L. A. (2013). Nitrate in the Mississippi River and its tributaries, 1980-2010: an update. U.S. Geological Survey Scientific Investigations Report 2013-5169. doi: 10.3133/sir20135169

Murphy, R. B., Kemp, W. M., and Ball, W. P. (2011). Long-term trends in Chesapeake Bay seasonal hypoxia, stratification, and nutrient loading. Estuaries Coasts 34, 1293-1309. doi: 10.1007/s12237-011-9413-7

Murray, C. J., Müller-Karulis, B., Carstensen, J., Conley, D. J., Gustafsson, B. G., and Andersen, J. H. (2019). Past, present and future eutrophication status of the Baltic Sea. Front. Mar. Sci. 6:2. doi: 10.3389/fmars.2019.0002
Neumann, T., Eilola, K., Gustafsson, B., Muller-Karulis, B., Kuznetsov, I., Meier, H. E. M., et al. (2012). Extremes of temperature, oxygen and blooms in the Baltic sea in a changing climate. Ambio 41, 574-585. doi: 10.1007/s13280-012-0321-2

Nishijima, W., Umehara, A., Sekito, S., Okuda, T., and Nakai, S. (2016). Spatial and temporal distributions of Secchi depths and chlorophyll $a$ concentrations in the Suo Nada of the Seto Inland Sea, Japan, exposed to anthropogenic nutrient loading. Sci. Total Environ. 571, 543-550. doi: 10.1016/j.scitotenv.2016.07.020

Nixon, S. W. (2009). Eutrophication and the macroscope. Hydrobiologia 629, 5-19. doi: 10.1007/s10750-009-9759-z

Oelsner, G. P., and Stets, E. G. (2019). Recent trends in nutrient and sediment loading to coastal area of the conterminous U.S.: insights and global context. Sci. Total Environ. 654, 1225-1240. doi: 10.1016/j.scitotenv.2018. 10.437

Oguz, T. (ed.). (2008). State of the Black Sea (2001-2006/7). Istanbul: Commission on the Protection of the Black Sea Against Pollution, 421.

Oguz, T., and Velicova, V. (2010). Abrupt transition of the northwestern Black Sea shelf ecosystem from a eutrophic to an alternative pristine state. Mar. Ecol. Prog. Ser. 405, 231-242. doi: 10.3354/meps08538

O'Higgins, T., Farmer, A., Daskolov, G., Knudsen, S., and Mee, L. (2014). Achieving good environmental status in the Black Sea: scale mismatches in environmental management. Ecol. Soc. 19:54. doi: 10.5751/ES-06707-190354

Osmond, D. L., Hoag, D. L. K., Luloff, A. E., Meals, D. W., and Neas, K. (2015). Farmers' use of nutrient management: lessons from watershed case studies. J. Environ. Qual. 44, 382-390. doi: 10.2134/jeq2014.02.0091

Paerl, H. W., Otten, T. G., and Kudela, R. (2018). Mitigating the expansion of harmful algal blooms across the freshwater-to-marine continuum. Environ. Sci. Techol. 52, 5519-5529. doi: 10.1021/acs.est.7b05950

Paerl, H. W., Scott, J. T., McCarthy, M. J., Newell, S. E., Gardner, W. S., Havens, K. E., et al. (2016). It takes two to tango: when and where dual nutrient ( $\mathrm{N} \&$ P) reductions are needed to protect lakes and downstream ecosystems. Environ. Sci. Technol. 50, 10805-10813. doi: 10.1021/acs.est.6b02575

Pavlidou, A., Simboura, N., Rousselaki, E., Tsapakis, M., Pagou, K., Drakopoulou, P., et al. (2015). Methods of eutrophication assessment in the context of the water framework directive: examples from the Eastern Mediterranean coastal areas. Cont. Shelf Res. 108, 156-168. doi: $10.1016 /$ j.csr.2015.05.013

Poole, C. A., Skaggs, R. W., Youssef, M. A., Chescheir, G. M., and Crozier, C. R. (2018). Effect of drainage water management on nitrate nitrogen loss to tile drains in North Carolina. Trans. Am. Soc. Agric. Biol. Eng. 61, 233-244. doi: $10.13031 /$ trans. 12296

Qian, W., Gan, J., Liu, J., He, B., Lu, Z., Guo, X., et al. (2018). Current status of emerging hypoxia in a eutrophic estuary: the lower reach of the Pearl River Estuary, China. Estuar. Coast. Shelf Sci. 205, 58-67. doi: 10.1016/j.ecss.2018.03. 004

Rabalais, N. N., Turner, R. E., and Scavia, D. (2002). Beyond science into policy: Gulf of Mexico hypoxia and the Mississippi River. Bioscience 52, 129-142. doi: 10.1641/0006-3568(2002)052[0129:BSIPGO]2.0.CO;2

Rabalais, N. N., Turner, R. E., Sen Gupta, B. K., Boesch, D. F., Chapman, P., and Murrell, M. C. (2007). Hypoxia in the northern Gulf of Mexico: does the science support the plan to reduce, mitigate, and control hypoxia. Estuaries Coast. 30, 753-772. doi: 10.1007/bf02841332

Rabotyagov, S. S., Campbell, T. D., White, M., Arnold, J. G., Atwood, J., Norfleet, M. L., et al. (2014). Cost-effective targeting of conservation investments to reduce the northern Gulf of Mexico hypoxic zone. Proc. Natl. Acad. Sci. U.S.A. 11, 18530-18535. doi: 10.1093/pnas.14505837111

Reusch, T. B. H., Dierking, J., Andersson, H. C., Bonsdorff, E., Carstensen, J., Casini, M., et al. (2018). The Baltic Sea as a time machine for the future coastal ocean. Sci. Adv. 4:eaar8195. doi: 10.1126/sciadv.aar8195

Ribaudo, M., Key, N., and Sneeringer, S. (2016). The potential role of a nitrogen compliance policy in mitigating Gulf hypoxia. Appl. Econ. Perspect. Policy 3, 458-478. doi: 10.1093/aepp/ppw029

Riemann, B., Carstensen, J., Dahl, K., Fossing, H., Hansen, J. W., Jakobsen, H. H., et al. (2016). Recovery of Danish coastal ecosystems after reductions in nutrient loadings: a holistic ecosystem approach. Estuaries Coast. 39, 82-97. doi: 10. 1007/s12237-015-9980-0

Robertson, D. M., and Saad, D. A. (2014). SPARROW models used to understand nutrient sources in the Mississippi/Atchafalaya River Basin. J. Environ. Qual. 42, 1422-1440. doi: 10.2134/jeq2013.02.0066 
Robertson, G. P., Hamilton, S. K., Barham, B. L., Dale, B. E., Izaurralde, R. C., Jackson, R. D., et al. (2017). Cellulosic biofuel contributions to a sustainable energy future: choices and outcomes. Science 356:eaal2324. doi: 10.1126/ science.aal 2324

Romero, E., Garnier, J., Lassaletta, L., Billen, G., Le Gendre, R., Riou, P., et al. (2013). Large-scale patterns of river inputs in southwestern Europe: seasonal and interannual variations and potential eutrophication effects at the coastal zone. Biogeochemistry 113, 481-505. doi: 10.1007/s10533-0129778-0

Romero, E., Le Gendre, R., Garnier, J., Billen, G., Fisson, C., Silvestre, M., et al. (2016). Long-term water quality in the lower Seine: lessons learned over 4 decades of monitoring. Environ. Sci. Policy 58, 141-154. doi: 10.1016/j.envsci. 2016.01.016

Rosensweig, M. L. (2003). Reconciliation ecology and the future of species diversity. Oryx 37, 194-205. doi: 10.1017/S0030605303000371

Rowe, G. T., and Chapman, P. (2002). Continental shelf hypoxia: some nagging questions. Gulf Mex. Sci. 20, 155-160. doi: 10.18785/goms.2002.08

Saraiva, S., Meier, H. E. M., Andersson, H., Höglund, A., Dieterich, C., Gröger, M., et al. (2018). Baltic sea ecosystem responses to various nutrient load scenarios in present and future climates. Clim. Dyn. 51, 1-19. doi: 10.1007/s00382-0184330-0

Sattar, M. A., Kroeze, C., and Storkal, M. (2014). The increasing impact of food production on nutrient export by rivers to the Bay of Bengal 1970-2050. Mar. Pollut. Bull. 80, 168-178. doi: 10.1016/j.marpolbul.2014.01.017

Savage, C., Leavitt, P. R., and Elmgren, R. (2010). Effects of land use, urbanization, and climate variability on coastal eutrophication in the Baltic Sea. Limnol. Oceanogr. 55, 1033-1046. doi: 10.4319/lo.2010.55.3.1033

Savchuk, O. P. (2018). Large-scale nutrient dynamics in the Baltic Sea, 1970-2016. Front. Mar. Sci. 5:95. doi: 10.3389/fmars.2018.00095

Scavia, D., Bertani, I., Obenour, D. R., Turner, R. E., Forrest, D. R., and Katin, A. (2017). Ensemble modeling informs hypoxia management in the northern Gulf of Mexico. Proc. Natl. Acad. Sci. U.S.A. 114, 8823-8828. doi: 10.1073/pnas. 1705293114

Scavia, D., Dubravko, J., Daniel, R., Obenour, J., Kevin, C., and Lixia, W. (2019). Hypoxic volume is more responsive than hypoxic area to nutrient load reductions in the northern Gulf of Mexico - and it matters to fish and fisheries. Environ. Res. Lett. 14:024012. doi: 10.1088/1748-9326/aaf938

Schaffelke, B., Fabricius, K., Kroon, F., Brodie, J., De'ath, G., Shaw, R., et al. (2018). Support for improved quality control but misplaced criticism of GBR science. Mar. Pollut. Bull. 129, 357-363. doi: 10.1016/j.marpolbul.2018. 02.054

Schindler, D. W., Hecky, R. E., Findlay, D. L., Stainton, M. P., Parker, B. R., Paterson, M., et al. (2008). Eutrophication of lakes cannot be controlled by reducing nitrogen input: results of a 37 year whole ecosystem experiment. Proc. Natl. Acad. Sci. U.S.A. 105, 11254-11258. doi: 10.1073/pnas.080510 8105

Schumacher, J., Dolch, T., and Reise, K. (2014). Transitions in sandflat biota since the 1930s: effects of sea-level rise, eutrophication and biological globalization in the tidal bay Königshafen, northern Wadden Sea. Helgol. Mar. Res. 68, 289-298. doi: 10.1007/s10152-014-0389-0

Shangguan, Y., Glibert, P. M., Alexander, J. A., Madden, C. J., and Mursako, S. (2017). Nutrients and phytoplankton in semienclosed lagoon systems in Florida Bay and their responses to changes in flow from Everglades restoration. Limnol. Oceanogr. 62, S327-S347. doi: 10.1002/lno.10599

Sherwood, E. T., Greening, H. S., Janicki, A. J., and Karlen, D. J. (2016). Tampa Bay estuary: monitoring long-term recovery through regional partnerships. Reg. Stud. Mar. Sci. 4, 1-11. doi: 10.1016/j.rsma.2015.05.005

Sigford, K. (2016). Decades of Delay: EPA Leadership Still Lacking in Protecting America's Great River. Mississippi River Collaborative. Available at: http://www.msrivercollab.org/wp-content/uploads/Decades-of-DelayMRC-Nov-2016.pdf

Sinha, E., Michalak, A. M., and Balaji, V. (2017). Eutrophication will increase during the 21 st century as a result precipitation changes. Science 377, 405-408. doi: 10.1126/science.aan2409

Smith, C. M., David, M. B., Mitchell, C. A., Masters, M. D., Anderson-Teixeira, J., Bernacchi, C. J., et al. (2013). Reduced nitrogen losses after conversion of row crop agriculture to perennial biofuel crops. J. Environ. Qual. 42, 219-228. doi: $10.2134 /$ jeq2012.0210
Snoeijs-Leijonmalm, P., Barnard, S., Elliott, M., Andrusaitis, A., Kononen, K., and Sirola, M. (2017). Towards better integration of environmental science in society: lessons from BONUS, the joint Baltic Sea environmental research and development programme. Environ. Sci. Policy 78, 193-209. doi: 10.1016/j. envsci.2017.10.004

Sprague, L. A., Hirsch, R. M., and Aulenbach, B. T. (2011). Nitrate in the Mississippi River and its tributaries, 1980 to 2008: are we making progress? Environ. Sci. Technol. 45, 7209-7216. doi: 10.1021/es20 $1221 \mathrm{~s}$

Staehr, P. A., Testa, J., and Carstensen, J. (2017). Decadal changes in water quality and net productivity of a shallow Danish estuary following significant nutrient reductions. Estuaries Coast. 40, 63-79. doi: 10.1007/s12237-016-0117-x

Steffen, W., Richardson, K., Rockström, J., Cornell, S. E., Fetzer, I., Bennett, E. M., et al. (2015). Planetary boundaries: guiding human development on a changing planet. Science 347:1259855. doi: 10.1126/science.1259855

Strokal, M., and Kroeze, C. (2013). Nitrogen and phosphorus inputs to the Black Sea in 1970-2050. Reg. Environ. Change 13, 179-192. doi: 10.1007/s10113-0120328-z

Strokal, M., Yang, H., Zhang, Y., Kroeze, C., Li, L., Luan, S., et al. (2014). Increasing eutrophication in the coastal seas of China from 1970 to 2050. Mar. Pollut. Bull. 85, 123-140. doi: 10.1016/j.marpolbul.2014.06.011

Swaney, D. P., Howarth, R. W., and Hong, B. (2018). Nitrogen use efficiency and crop production: patterns of regional variation in the United States, 1987-2012. Sci. Total Environ. 635, 498-511. doi: 10.1016/j.scitotenv.2018.04.027

Testa, J. M., Kemp, W. M., and Boynton, W. R. (2018). Season-specific trends and linkages of nitrogen and oxygen cycles in Chesapeake Bay. Limnol. Oceanogr. 63, 2045-2064. doi: 10.1002/lno.10823

Tomasko, D., Alderson, M., Burnes, R., Hecker, J., Leverone, J., Raulerson, G., et al. (2018). Widespread recovery of seagrass coverage in Southwest Florida (USA): temporal and spatial trends and management actions responsible for success. Mar. Pollut. Bull. 135, 1128-1137. doi: 10.1016/j.marpolbul.2018. 08.049

Tong, Y., Zhao, Y., Zhen, G., Chi, J., Liu, X., Lu, Y., et al. (2015). Nutrient loads flowing into coastal waters from the main rivers of China (2006-2012). Sci. Rep. 5:16678. doi: 10.1038/srep16678

Tournebize, J., Chaumont, C., and Mander, U. (2017). Implications for constructed wetlands to mitigate nitrate and pesticide pollution in agricultural drained watersheds. Ecol. Eng. 103, 415-425. doi: 10.1016/j.ecoleng.2016.02.014

Turner, R. E., and Rabalais, N. N. (1991). Changes in the Mississippi River this century: implications for coastal food webs. Bioscience 41, 140-147. doi: 10 . 2307/1311453

Vahtera, E., Conley, D. J., Gustafsson, B. G., Kuosa, H., Pitkänen, H., Savchuk, O. P., et al. (2007). Internal ecosystem feedbacks enhance nitrogen-fixing cyanobacteria blooms and complicate management in the Baltic Sea. Ambio 36, 186-194. doi: 10.1579/0044-7447(2007)36[186:IEFENC]2.0.CO;2

van Beusekom, J. E. E. (2005). A historic perspective on Wadden Sea eutrophication. Helgol. Mar. Res. 59, 45-54. doi: 10.1007/s10152-004-0206-2

Van Meter, K. J., Van Cappelan, P., and Basu, N. B. (2018). Legacy nitrogen may prevent achievement of water quality goals in the Gulf of Mexico. Science 369, 427-430. doi: 10.1126/science.aar4462

Vero, S. E., Basu, N., Van Meter, K., Richards, K. G., Mellander, P.-E., Healy, M. G., et al. (2018). Review: the environmental status and implications of the nitrate time lag in Europe and North America. Hydrogeol. J. 26, 7-22. doi: 10.1007/s10040-017-1650-9

Viaroli, P., Soana, E., Pecora, S., Laini, A., Naldi, M., Fano, E. A., et al. (2018). Space and time variations of watershed $\mathrm{N}$ and $\mathrm{P}$ budgets and their relationships with reactive $\mathrm{N}$ and $\mathrm{P}$ loadings in a heavily impacted river basin (Po river, Northern Italy). Sci. Total Environ. 639, 1574-1587. doi: 10.1016/j.scitotenv.2018. 05.233

Voulvoulis, N., Arpon, K. D., and Giakoumis, T. (2017). The EU Water Framework Directive: from great expectations to problems with implementation. Sci. Total Environ. 575, 358-366. doi: 10.1016/j.scitotenv.2016.09.228

Walve, J., Sandberg, M., Larsson, U., and Lännergen, C. (2018). A Baltic Sea estuary as a phosphorus source and sink after drastic load reduction: seasonal and long-term mass balances for the Stockholm inner archipelago for 1968-2015. Biogeosciences 15, 3003-3025. doi: 10.5194/bg-15-3003-2018

Wang, H., Dai, M., Liu, J., Kao, S.-J., Zhang, C., Cai, W.-J., et al. (2016). Eutrophication-driven hypoxia in the East China Sea off the Changjiang 
Estuary. Environ. Sci. Technol. 50, 2255-2263. doi: 10.1021/acs.est5b0 6211

Wang, H., Hu, X., Rabalais, N. N., and Brandes, J. (2018). Drivers of oxygen consumption in the Gulf of Mexico hypoxic waters-a stable carbon isotope perspective. Geophys. Res. Lett. 45, 528-538. doi: 10.1029/2018GL078571

Wetzel, P. R., Davis, S. E., van Lent, T., Davis, M., and Henriquez, H. (2017). Science synthesis for management as a way to advance ecosystem restoration: evaluation of restoration scenarios for the Florida Everglades. Restor. Ecol. 25, S4-S17. doi: 10.1111/rec.12566

Wu, H., Wu, T., and Bai, M. (2018). Mega estuarine constructions modulate the Changjiang River plume extension in adjacent seas. Estuaries Coast. 41, 1234-1252. doi: 10.1007/s12237-017-0357-4

Wu, Y., Xi, X., Tang, X., Luo, D., Gu, B., Lam, S. K., et al. (2018). Policy distortions, farm size, and the overuse of agricultural chemicals in China. Proc. Natl. Acad. Sci. U.S.A. 115, 7010-7015. doi: 10.1073/pnas.1806645115

Wulff, F., Eyre, B. D., and Johnstone, R. (2011). Nitrogen versus phosphorus limitation in a subtropical coastal embayment (Moreton Bay; Australia): implications for management. Ecol. Model. 222, 120-130. doi: 10.1016/j. ecolmodel.2010.08.040

Wulff, F., Humborg, C., Andersen, H. E., Blicher-Mathiesen, G., Czajkowski, M., Elofsson, K., et al. (2014). Reduction of Baltic Sea nutrient inputs and allocation of abatement costs within the Baltic Sea catchment. Ambio 43, 11-25. doi: 10.1007/s13280-013-0484-5

Xu, J., Yin, K., Liu, H., Lee, J. H. W., Anderson, D. M., Ho, A. Y. T., et al. (2010). A comparison of eutrophication impacts in two harbours in Hong Kong with different hydrodynamics. J. Mar. Syst. 83, 276-286. doi: 10.1016/j.jmarsys.2010. 04.002

Yamamoto, T. (2003). The Seto Inland Sea-eutrophic or oligotrophic? Mar. Pollut. Bull. 47, 37-42. doi: 10.1016/S0025-326X(02)00416-2

Yanagi, T. (ed.). (2015). Eutrophication and Oligotrophication in Japanese Estuaries: The Present Status and Future Tasks. Berlin: Springer, 97. doi: 10.1007/978-94017-9915-7
Zhang, Q., Brady, D. C., Boynton, W. R., and Ball, W. P. (2015). Long-term trends of nutrients and sediment from the nontidal Chesapeake watershed: an assessment of progress by river and season. J. Am. Water Res. Assoc. 51, 1534-1555. doi: 10.1111/1752-1688.12327

Zhang, X., Mauzerall, D. L., Davidson, E. A., Kanter, D. R., and Cai, R. (2015). The economic and environmental consequences of implementing nitrogen-efficient technologies and management practices in agriculture. J. Environ. Qual. 44, 312-324. doi: 10.2134/jeq2014.03.0129

Zhang, Q., Hirsch, R. M., and Ball, W. P. (2016). Long-term changes in sediment and nutrient delivery from Conowingo Dam to Chesapeake Bay: effects of reservoir sedimentation. Environ. Sci. Technol. 50, 1877-1886. doi: 10.1021/acs. est.5b04073

Zhang, Q., Murphy, R. R., Tian, R., Forsyth, M., Trentacoste, E. M., Keisman, J., et al. (2018). Chesapeake Bay's water quality condition has been recovering: insights from a multimetric indicator assessment of thirty years of tidal monitoring data. Sci. Total Environ. 637-638, 1617-1625. doi: 10.1016/j. scitotenv.2018.05.025

Zhu, Z.-Y., Zhang, J., Wu, Y., Zhang, Y.-Y., Lin, J., and Liu, S.-M. (2011). Hypoxia off the Changjiang (Yangtze River) estuary: oxygen depletion and organic matter decomposition. Mar. Chem. 125, 108-116. doi: 10.1016/j.marchem.2011. 03.005

Conflict of Interest Statement: The author declares that the research was conducted in the absence of any commercial or financial relationships that could be construed as a potential conflict of interest.

Copyright (c) 2019 Boesch. This is an open-access article distributed under the terms of the Creative Commons Attribution License (CC BY). The use, distribution or reproduction in other forums is permitted, provided the original author(s) and the copyright owner(s) are credited and that the original publication in this journal is cited, in accordance with accepted academic practice. No use, distribution or reproduction is permitted which does not comply with these terms. 